\title{
Developmental Regulation of the Hypothalamic Metabotropic Glutamate Receptor mGluR1
}

\author{
Anthony N. van den Pol, ${ }^{1,2}$ Laura Kogelman, ${ }^{1}$ Prabhat Ghosh, ${ }^{1}$ Patricia Liljelund, ${ }^{1}$ and Craig Blackstone ${ }^{3}$ \\ ${ }^{1}$ Section of Neurosurgery, Yale University School of Medicine, New Haven, Connecticut 06510, ${ }^{2}$ Department of Biological \\ Sciences, Stanford University, Stanford, California 94305, and ${ }^{3}$ Department of Neuroscience and Howard Hughes Medical \\ Institute, Johns Hopkins University School of Medicine, Baltimore, Maryland 21205
}

The expression of the metabotropic glutamate receptor mGluR1 was studied with Northern and Western blot analysis, with immunocytochemistry, and with $\mathrm{Ca}^{2+}$ digital imaging in the developing rat hypothalamus. mGluR1 is coupled to a $G$ protein and activation by glutamate and related agonists leads to intracellular phosphotidylinositol hydrolysis and $\mathrm{Ca}^{2+}$ mobilization. mGluR1 RNA could be detected in embryonic hypothalamus, and by the day of birth and prior to the primary period of synaptogenesis, both mGluR1 RNA and protein were strongly expressed. In parallel experiments with digital imaging of cultured hypothalamic cells, some embryonic day 18 hypothalamic neurons and many astrocytes after $3 \mathrm{~d}$ in vitro showed $\mathrm{Ca}^{2+}$ responses to quisqualate and $t-A C P D$, and to glutamate in the absence of extracellular $\mathrm{Ca}^{2+}$. A greater number of embryonic neurons responded to NMDA than to agonists of the metabotropic receptor. With increased development time in culture, the number of neurons that responded to metabotropic glutamate receptor agonists increased.

In the adult hypothalamus, mGluR1-immunoreactive neurons were widespread, and particularly dense in the dorsomedial, lateral, and anterior hypothalamus/preoptic areas, and in the mammillary body. Strongly immunoreactive cells were interspersed among neurons with no immunoreactivity. In developing neurons a diffuse immunostaining appeared along dendrites and somata. With time, beginning in the first week after birth, strongly stained puncta appeared, possibly associated with synaptic specializations. These puncta were numerous on dendrites of some adult neurons, and were the most strongly stained regions of neurons. Neurons developing in vitro at low neuron densities showed a development of mGluR 1 immunoreactivity similar to that of neurons in vivo, but with a delayed progression of immunostaining. We found no obvious staining of axons or of astrocytes. A strong expression of mGluR1 protein was found in the hypothalamus during the first 2 postnatal weeks; this expression was partially reduced in adults. In contrast, cerebellum showed no reduction in mGluRt protein in adults. Together these data

Received July 20, 1993; revised Oct. 29, 1993; accepted Dec. 16, 1993.

We thank Dr. Y. Yang and V. Cao for technical assistance, Dr. R. Huganir for his encouragement, and Dr. S. Nakanishi for cDNA coding for mGluR1. Grant support was provided by NIH NS 16296, NS 10174, and the AFOSR to A.N.v. and NIH GM 07309 to C.B.

Correspondence should be addressed to Anthony N. van den Pol, Department of Biological Sciences, Stanford University, Stanford, CA 94305.

Copyright (C) 1994 Society for Neuroscience $0270-6474 / 94 / 143816-19 \$ 05.00 / 0$ suggest a complex regulation of mGluR1 during development, with sufficient expression of functional receptors in the developing hypothalamus to modulate morphogenesis and synaptogenesis, and later to play a role in transduction of glutamate signals in the adult. Different regions of the brain showed dramatic differences in the way each expresses mGluR1 during development.

IKey words: calcium, neuroendocrine, suprachiasmatic nucleus, paraventricular nucleus, quisqualate, t-ACPD, NMDA, astrocytes]

Glutamate receptors can be divided into two general groups, the ionotropic group which includes the AMPA, kainate, and NMDA-type receptors that open cation channels, and the metabotropic receptors that activate second messenger systems via a $G$ protein. Activation of the metabotropic receptor leads to increases in phosphotidylinositol (PI) hydrolysis, resulting in formation of diacylglycerol and $\mathrm{IP}_{3}$ and mobilization of $\mathrm{Ca}^{2+}$ from intracellular stores (Furuya et al., 1989); these second messengers modulate a wide variety of enzymatic pathways, gene expression, and cellular growth and differentiation (Mayer and Miller, 1990; Schoepp et al., 1990; Shigemoto et al., 1992; Yuzaki and Mikoshiba, 1992). Stimulation of mGluRl has also been reported to induce the formation of CAMP and the release of arachidonic acid (Aramori and Nakanishi, 1992; Fotuhi et al., 1992). A number of genes coding for both ionotropic (Sugiyama et al., 1987; Hollmann et al., 1989; Moriyoshi et al., 1991) and metabotropic (Houamed et al., 1991; Masu et al., 1991; Abe et al., 1992; Tanabe et al., 1992) glutamate receptors have been cloned. During development these glutamate receptors may be expressed prior to substantial synapse formation and may play a role in influencing the organization of the developing brain. A growing body of evidence indicates that glutamate may be released early in development (LoTurco et al., 1991) and may modulate neuronal structure and connections (Mattson et al., 1988; Dudek and Bear, 1989; Cline and Constantine-Paton, 1990; Constantine-Paton et al., 1991).

In preliminary work we found a strong expression of the mGluR 1 metabotropic receptor in the hypothalamus in the developing rat brain. Previous functional studies have suggested that the hypothalamic metabotropic receptor is extremely active in the nconatal brain in inducing PI hydrolysis, but that it is almost inactive in the adult brain (Palmer et al., 1990; Sortino et al., 1991), making the hypothalamus a useful model for studying developmental regulation of the metabotropic receptor. Parallel developmental studies in some, but not all, regions of the 
brain have demonstrated a similar elevated functional activity of the metabotropic receptor in neonatal neurons compared with adult neurons (Nicoletti et al., 1986; Dudek et al., 1989; Guiramand et al., 1989; Palmer et al., 1990; Balduini et al., 1991; Boss et al., 1992). One hypothesis for the strong neonatal functional activation of the metabotropic receptor is the presence of large numbers of receptors during that time period that subsequently diminish with age (Guiramand et al., 1989).

Within the hypothalamus glutamate appears to play an important role as a primary excitatory neurotransmitter. IIigh levels of glutamate are found in hypothalamic presynaptic boutons hy ultrastructural immunocytochemistry (Meeker et al., 1989; van den Pol, 1991). In previous work we have demonstrated with intracellular recording in adult slices (van den Pol et al., 1990) and with patch-clamp recording of pairs of developing synaptically coupled neurons in vitro (van den Pol and Trombley, 1993) that glutamate may be the major excitatory transmitter of the medial hypothalamus. We have also shown with in situ hybridization and Northern blots that both the NMDA and non-NMDA ionotropic glutamate receptor genes are expressed throughout the adult hypothalamus (van den Pol et al., 1994). That functional glutamate receptors are expressed in hypothalamic neurons is supported by electrophysiology (Arnauld et al., 1983; Swandulla and Misgeld, 1990), $\mathrm{Ca}^{2+}$ imaging studies (van den Pol et al., 1990, 1992), and neuroendocrine perturbation studies (Brann and Mahesh, 1992).

To study the developmental regulation of the metabotropic glutamate receptor mGluR 1 , which is widely expressed in the developing and adult CNS, we examined the mRNA levels with Northern blots and the protein levels with Western blots at different stages of hypothalamic development. This particular receptor is interesting developmentally because of its role in modulation of intracellular $\mathrm{Ca}^{2+}$ (Nakanishi, 1992) and the ability of glutamate agonists to alter mGluR1 RNA levels in developing neurons (Bessho et al., 1993). Other brain regions including the hippocampus and cerebellum were used for comparative examination of $\mathrm{mGluR}$ levels. To study the change in the metabotropic receptor expression at the cellular level, we immunostained a series of brains from embryo, neonate, and adult rats, with a focus on the hypothalamus where the distribution of metabotropic receptors has not been examined previously. Immunostaining was done in parallel on developing neurons in culture. To assess the functional activity of the metabotropic glutamate receptor in developing hypothalamic neurons, we used $\mathrm{Ca}^{2+}$ digital imaging of cultured hypothalamic cells.

An abstract of some of this work has been presented (van den Pol et al., 1993).

\section{Materials and Methods}

Immunocytochemistry. Postnatal day 1 (P1), P7, P21, and adult SpragueDawley rats were anesthetized with hypothermia and/or Nembutal and perfused transcardially with cold $0.1 \mathrm{M}$ phosphate-buffered $0.9 \%$ saline (PBS), followed by 4\% paraformaldehyde prepared in 0.1 м PBS. Fourteen neonatal and 12 adult brains were dissected out and allowed to fix in $4 \%$ paraformaldehyde for at least $24 \mathrm{hr}$ before sectioning. Four embryonic day 18 (E18) brains were fixed in $1 \%$ acrolein for $2 \mathrm{hr}$ and then in $4 \%$ paraformaldehyde overnight. The brains of animals younger than Pl were cut into $30 \mu \mathrm{m}$ sections using a cryostat. These brains were cryoprotected in $15 \%$ and then $30 \%$ sucrose for $25 \mathrm{hr}$ prior to cutting. Sections were either suspended in washing buffer or thaw mounted on gelatin-coated slides heated to $45^{\circ} \mathrm{C}$, and then dried for $15 \mathrm{~min}$ before washing. The rest of the procedure was identical to that used for the sections cut from older animals. The brains of older animals were cut into 30-50 $\mu \mathrm{m}$ sections using a Vibratome.

Slices were washed in $0.1 \mathrm{~m}$ phosphate buffer containing $1 \%$ bovine serum albumin (BSA), $0.1 \%$ Tris, $0.1 \%$ lysine, and $0.4 \%$ Triton $\mathrm{X}-100$. Slices were blocked in washing buffer with $2 \%$ normal goat serum for at least $30 \mathrm{~min}$ and were then incubated in primary antibody at $10^{\circ} \mathrm{C}$ for 2 to $3 \mathrm{~d}$. Rabbit anti-mGluR $1 \alpha$ antibodies (Martin et al., 1992) or GluR2/3 antibodies (Blackstone et al., 1992a) used as controls were diluted up to $1: 1000$ in blocking buffer containing $0.01 \%$ sodium azide to prevent contamination during the incubation period. Slices were washed a second time before the $1-2 \mathrm{hr}$ incubation in secondary antibody, biotinylated goat anti-rabbit IgG. For histochemical staining, sections were washed and then incubated in the avidin and biotinylated horseradish peroxidase macromolecular complex (Vectastain Elite ABC $\mathrm{Kit}$ ) in blocking buffer for $30 \mathrm{~min}$. Sections were then rinsed twice in washing buffer and once in $0.1 \mathrm{M}$ Tris buffer, $\mathrm{pH} 7.2$, and then reacted with $3,3^{\prime}$-diaminobenzidine $(1 \mathrm{mg} / \mathrm{ml})$ in the presence of hydrogen peroxide. Sections were then treated with $0.1 \%$ osmium tetroxide to enhance contrast of the immunoreactive neurons, dehydrated, and coverslipped.

The mGluR $1 \alpha$ antibodies were generated against a peptide (KPNVTYASVILRDYKQSSSTL) corresponding to the C-terminal 20 amino acids (residues 1 180-1 199) of the predicted polypeptide sequence encoded by the mGluR $1 \alpha$ cDNA in rat brain (Houamed et al., 1991; Masu et al., 1991; Tanabe et al., 1992). An N-terminal lysine residue was added to the peptide to facilitate coupling of the peptide to the carrier protein. Antisera against carrier protein-conjugated peptides were raised in New Zealand White rabbits. The mGluR $1 \alpha$ antiserum used in the present study was affinity purified on a column of BSA-conjugated mGluR $1 \alpha$ peptide bound to Affi-Gel 15 (Bio-Rad). The antibodies have been characterized previously, and bind specifically to the mGluR 1 protein on Western blots of synaptosomal membranes (Blackstone et al., 1992a; Martin et al., 1992). Adsorption controls in which the synthetic peptide $(10-50 \mu \mathrm{M})$ was incubated with the antibodies prior to their use blocked immunostaining on sections, in culture, and on Western blots.

Of all known metabotropic glutamate receptors, mGluR5 is the most similar to mGluR $1 \alpha$. Even so, the C-terminus of the mGluR 5 protein shares only a $50 \%$ (10 of 20 ) amino acid identity with the mGluR $1 \alpha$ peptide used for antibody production (Abe et al., 1992). The general pattern of immunostaining with the mGluR $1 \alpha$ antibody (Martin et al., 1992) resembles much more closely the mRNA distribution of mGluR 1 (Shigemoto et al., 1992) than mGluR5 (Abe et al., 1992). Finally, regions high in mGluR5, such as striatum, show little immunoreactivity using this antibody preparation. Thus, it seems likely that cross-reactivity with mGluR5, if any, is minimal. No cross-reactivity with other metabotropic glutamate receptors has been found, and would not be expected given the lack of similarity of the amino acid sequence used for antibody generation here and the known sequences of other cloned metabotropic receptors (Tanabe et al., 1992). The mGluR $1 \alpha$ antibody used in the present study would not recognize mGluR $1 b$ or mGluR $1 c$ (Pin et al., 1992). Given the lack of homology between metabotropic and ionotropic glutamate receptors, no cross-reactivity of the antiserum used in the present study with ionotropic receptors would be expected.

Northern blots $-R N A$. Total cellular RNA was obtained from brain tissue by extraction in guanidinium thiocyanate followed by overnight sedimentation of total RNA through a cesium chloride cushion, phenolchloroform extraction and, finally, ethanol precipitation of the resulting pellet after dissolving in buffer containing $10 \mathrm{~mm}$ Tris $7.5,1 \mathrm{mM}$ EDTA, $0.3 \mathrm{~m}$ sodium acetate, and $0.2 \%$ SDS. Three brains were removed for each age.

Samples $(10 \mu \mathrm{g})$ of total RNA were electrophoresed on $1 \%$ agarose, $2.2 \mathrm{M}$ formaldehyde gels in MOPS buffer. RNA was transferred by blotting to nylon filters (Nytran, Schleicher and Schuell) overnight in $10 \times$ sodium citrate/sodium chloride (SSC). Following baking al $80^{\circ} \mathrm{C}$ for $2 \mathrm{hr}$, filters were hybridized at $42^{\circ} \mathrm{C}$ overnight in $50 \%$ deionized formamide, $10 \%$ dextran sulfate, $1 \mathrm{M} \mathrm{NaCl}, 1 \%$ SDS, and $150 \mu \mathrm{g} / \mathrm{ml}$ denatured salmon sperm DNA. A $3.5 \mathrm{~kb}$ insert from the pmGRl metabotropic glutamate receptor plasmid (a generous gift of Dr. S. Nakanishi) was obtained by digestion with EcoRI and Xbal restriction enzymes and subsequent isolation and purification. A rat $1 \mathrm{~kb}$ actin probe cut with PstI and XbaI was used as a control for RNA loading on the gel. Probes were labeled with ${ }^{32} \mathrm{P}$-dCTP by the random hexamer primer extension method (Feinberg and Vogelstein, 1983), usually to specific activities of $2.5-5 \times 10^{8} \mathrm{cpm} / \mathrm{ml}$, and subsequently used at $3-4 \times 10^{6}$ 
ADULT MGLUR1 RNA

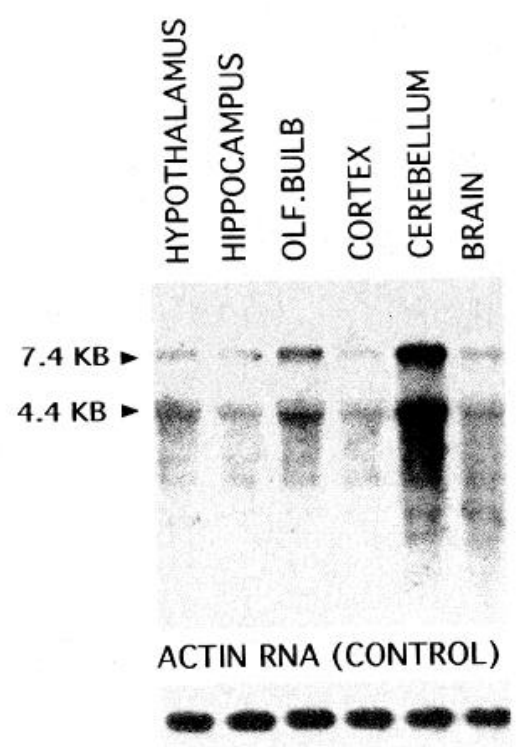

Figure 1. mGluR1 in different regions of the adult brain: Northern blot. The brain regions indicated in labels above each lane express different amounts of mGluR1 RNA in adult rats. The greatest expression is in the cerebellum. After stripping the blot, the blot was probed a second time for $\gamma$-actin, shown at the bottom. The consistent size and density of the actin bands confirms that similar amounts of RNA were loaded in each lane. Molecular weights ( 7.4 and $4.4 \mathrm{~kb})$ are shown by arrowheads (see Fig. 11 for further description). Multiple bands on Northern blots have been reported before with mGluR 1 (Houamed et al., 1991; Masu et al., 1992; Bessho et al., 1993), and may represent alternatively spliced forms of mGluR1 (Houamed et al., 1991; Abe et al., 1992; Pin et al., 1992). The higher-molecular-weight band likely represents mGluR $1 \alpha$, and the lower may represent mGluR $1 \mathrm{~b}$ and/or mGluR 1c.

$\mathrm{cpm} / \mathrm{ml}$ in the hybridization mix. Following hybridization, filters were washed successively with $2 \times$ SSC for $5 \mathrm{~min}$ at room temperature (three times); $2 \times \mathrm{SSC}, 1 \% \mathrm{SDS}$ for 30 to $45 \mathrm{~min}$ at $65^{\circ} \mathrm{C}$ (two times); and $0.2 \times$ SSC, $0.1 \%$ SDS for 30 to $45 \mathrm{~min}$ at $65^{\circ} \mathrm{C}$ (two times).

Western blots - protein. Whole brains and defined brain regions were dissected from 15 Sprague-Dawley rats of different ages and immediately frozen on dry ice. The tissues were stored at $-80^{\circ} \mathrm{C}$ until use. Protein extracts were prepared by individually homogenizing each tissue sample in a small precooled mortar and pestle maintained in dry ice throughout the procedure. Pulverized tissue was suspended in several hundred microliters of a modified buffer (Blackstone et al., 1992b) containing 20 mм Tris- $\mathrm{HCl}$ ( $\mathrm{pH} \mathrm{7.4),} 10 \%$ sucrose, and $0.1 \mathrm{~mm}$ PMSF as a protease inhibitor, and vortexed three times for $1 \mathrm{~min}$ with $1 \mathrm{~min}$ cooling intervals on ice. The samples were subsequently centrifuged for $10 \mathrm{~min}$ at 14,000 rpm in an Eppendorf centrifuge, and the resulting supernatant quick-frozen in aliquots as the working crude extract. The final protein concentration was about $10 \mathrm{mg} / \mathrm{ml}$, and the extracts were stable through repeated freeze-thaw cycles. Coomassie-stained SDS-polyacrylamide gels were routinely used to judge the concentration and quality of the extracts.

Western blots were carried out using $8 \%$ SDS-polyacrylamide gels run on a minigel apparatus (Hoefer); about $30 \mu \mathrm{g}$ of protein was loaded per lane. Samples were heated at $37^{\circ} \mathrm{C}$ for $1 \mathrm{hr}$ before adding the loading dye. The gels were transferred to nitrocellulose by electroblotting for 1 $\mathrm{hr}(100 \mathrm{~V})$, and the filter blocked for $24 \mathrm{hr}$ at $4^{\circ} \mathrm{C}$ in $0.5 \%$ nonfat dry milk and $0.1 \%$ Tween. Blots were then incubated with mGluR1 antibodies at a 1:1000 dilution in $10 \mathrm{~mm}$ Tris- $\mathrm{HCl}, 150 \mathrm{~mm} \mathrm{NaCl}, 0.05 \%$ Tween for $2 \mathrm{hr}$, washed three times for $10 \mathrm{~min}$ in the same buffer, and incubated for $1 \mathrm{hr}$ with horseradish peroxidase-conjugated donkey antirabbit immunoglobulin $\mathrm{G}$ (Amersham) diluted to $1: 1000$ in phosphatebuffered saline containing $0.1 \%$ Tween 20 and $5 \%$ nonfat dry milk. The blots were subsequently washed four times for $20 \mathrm{~min}$ in the same buffer,
MGLUR1 PROTEIN

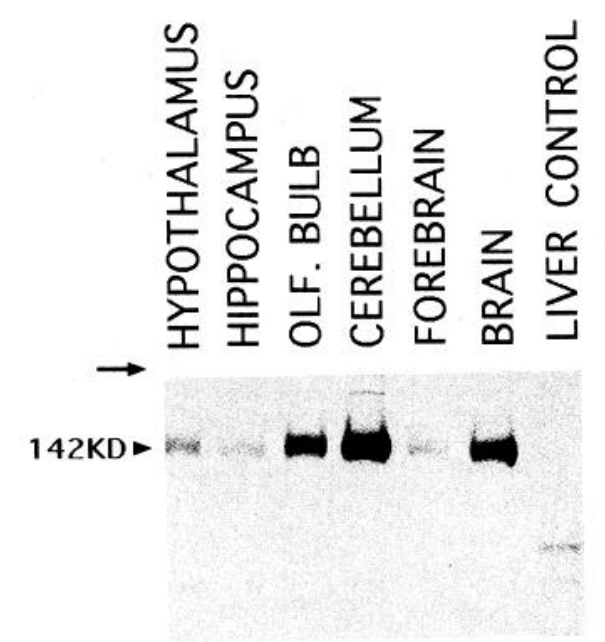

Figure 2. Different regions of the adult brain: Western blot. The highest levels of mGluR1 protein were found in the cerebellum, followed by the olfactory bulb, and then by hypothalamus, hippocampus, and forebrain. Liver showed no specific label for mGluR1, but a slight crossreactivity of the antibodies with a lower-molecular-weight protein could be detected. Arrow indicates the origin at the top of the gel. Molecular weight was determined with prestained high-molecular-weight SDSPAGE standards (Bio-Rad).

followed by four $20 \mathrm{~min}$ washes in phosphate-buffered saline minus the milk. Immunoreactive proteins were revealed using enhanced chemiluminescence (ECL, Amersham). Western blots were run in duplicate or triplicate with similar results.

Tissue culture. The hypothalami were dissected from 102 E18 rats, disaggregated in the presence of papain as describ t previously (van den Pol et al., 1992), and plated on polylysine (MI 560,000)-coated $22 \mathrm{~mm}$ square sterile glass coverslips. Cultures were : aintained in vitro for $3 \pm 1 \mathrm{~d}$ before use for digital imaging.

Some cultures $(n=90)$ were used for $\mathrm{Ca}^{2+}$ imagin and others $(n=$ 12) were used for immunocytochemistry. Immunc ining was performed in a manner similar to that used to stain bra : sections.

Calcium digital imaging. Cultured cells were washed ge..tly with HEPES buffer, and then loaded with fluo3 acetoxymethyl ester. Among known $\mathrm{Ca}^{2+}$ indicator dyes, fluo3 is the most sensitive, and is therefore optimally useful for the detection of minimal $\mathrm{Ca}^{2+}$ responses expected in embryonic cells after short times in culture. Cells were placed in a flowthrough chamber (Forscher et al., 1987) with a volume of about $185 \mu \mathrm{l}$ that could be serially perfused with glutamate agonists and antagonists. The chamber was placed on a Nikon inverted microscope fitted with an Optiquip $150 \mathrm{~W}$ xenon light source and a Sutter filter wheel and shutter assembly under computer control. Video frames were recorded on a Panasonic 2023 analog laser disk recorder at 1 or 2 sec intervals. Each recorded frame was the average of eight single video frames, gathered with an Image I Fluor system (Universal Imaging). To reduce phototoxicity and photobleaching, $95 \%$ of the light emitted by the light source was blocked with neutral density filters; a computer-controlled shutter was closed during the intervals when frames were not being averaged. A Hamamatsu C 2400 silicon intensified target (SIT) camera was used to capture video images.

Fluo3 calcium data are presented as the change in fluorescence over the baseline fluorescence for each cell $\left(\Delta F / F_{0}\right)$. This provides correction for differential dye loading, potential heterogeneity in the video field, and variations in video gain and offset. The equations that this is based on are described in detail elsewhere (Cornell-Bell et al., 1990; van den Pol et al., 1990; Finkbeiner, 1991, 1992).

The HEPES buffer used was as described before (Cornell-Bell et al., 1990; van den Pol et al., 1990), and contained 10 mM HEPES, $25 \mathrm{~mm}$ glucose, $1 \mathrm{~mm} \mathrm{MgCl}, 2.5 \mathrm{~mm} \mathrm{CaCl}_{2}$, and $137 \mathrm{~mm} \mathrm{NaCl}$. To reduce the magnesium blockade of the NMDA receptor, experiments with NMDA were done in the absence of $\mathrm{MgCl}_{2}$ with the addition of $2 \mu \mathrm{M}$ glycine. In experiments done with zero calcium, the HEPES buffer had no calcium, but did contain 3 mM EGTA. 

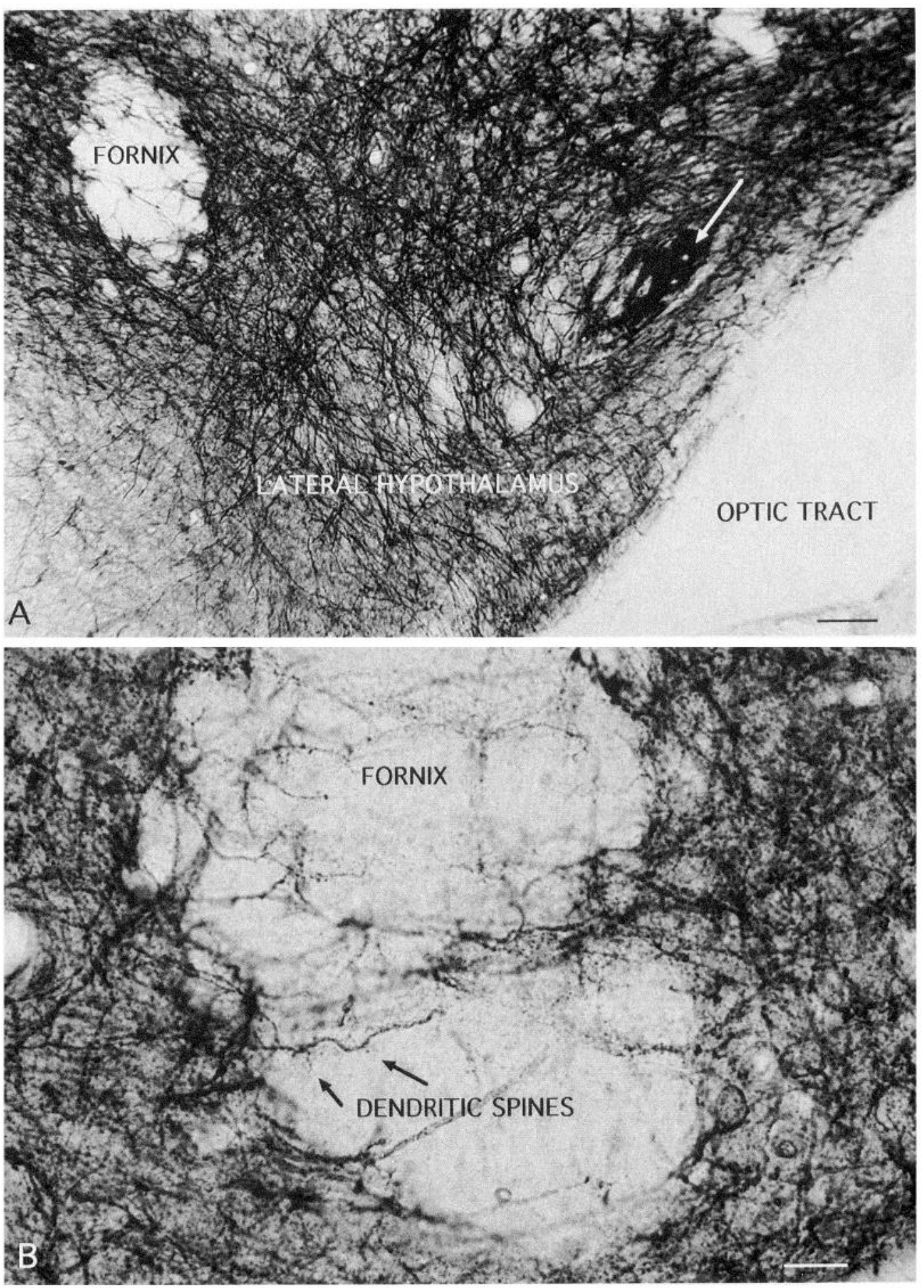

Figure 3. mGluR1-immunoreactive dendrites. A strong black staining of hypothalamic dendrites is found in the lateral hypothalamus, on the right side of the fornix. The white arrow points to a highly immunoreactive mass of cells that is also found in the same region on the contralateral side of the hypothalamus. No immunoreactive axons are found in the optic tract or in the fornix. $B$, Immunoreactive dendrites cross the fornix in a section caudal to the one shown in $A$. Small dendritic spines and appendages on these dendrites are also immunoreactive. Scale bars: $A$, 180 $\mu \mathrm{m} ; B, 85 \mu \mathrm{m}$.

Photomicrographs and blots in this article are digital images printed from a Kodak XL 7700 dye sublimation printer interfaced with a Macintosh lab computer. Images were scanned from Kodak Technical Pan or Kodachrome color film with a Kodak RFS 2035 film scanner prior to printing. Alternatively, some images were recorded electronically with a Newvicon or SIT video camera or with a Kodak DCS 200 digital camera coupled directly to a Nikon inverted microscope.

\section{Results}

mGluR1 RNA and protein in adult brain

RNA from the hypothalamus was compared with equal amounts of RNA from other regions of the brain including the olfactory bulb, cortex, hippocampus, cerebral cortex, and whole brain. 
Figure 4. mGluR1-immunoreactive neuron in dorsomedial hypothalamus. This neuron shows small immunoreactive puncta, most clearly seen on the dendrites (arrows), but also detectable on the perikaryon (double arrowhead). Scale bar, $10 \mu \mathrm{m}$.

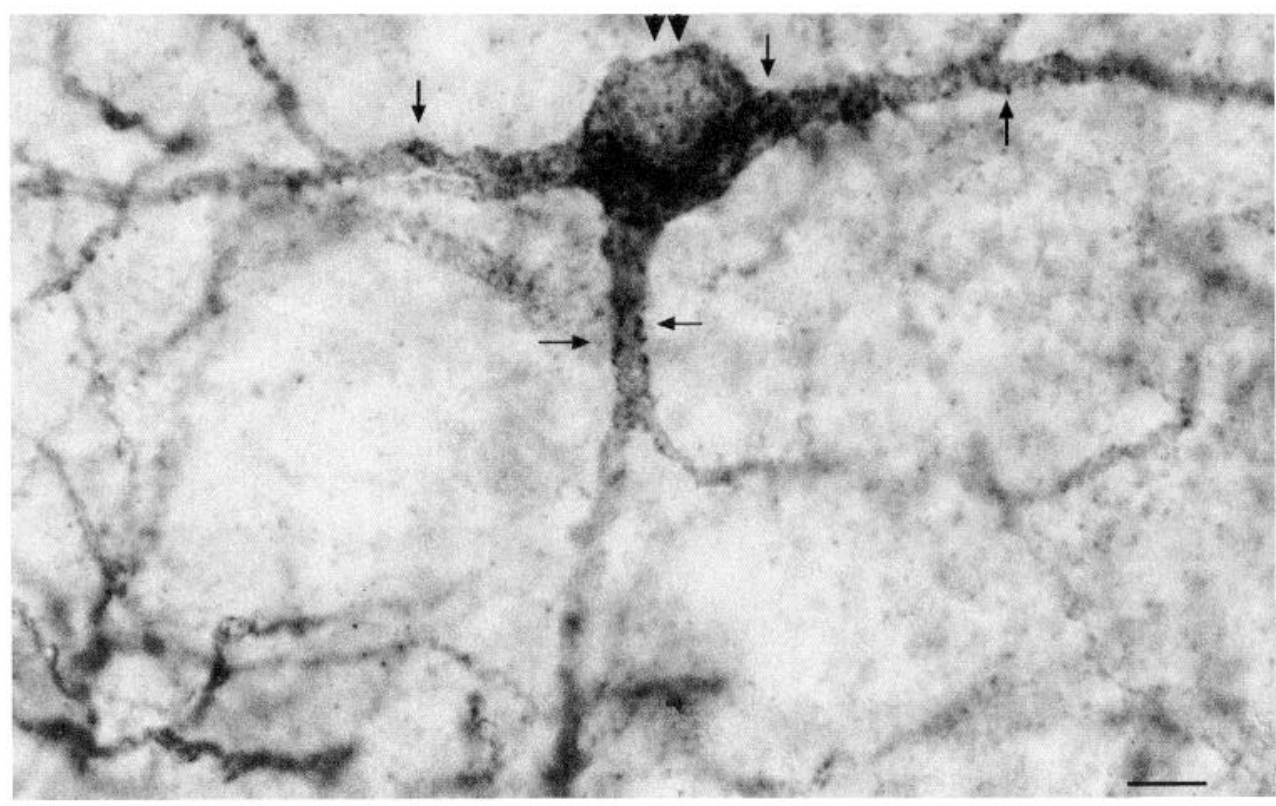

Among these regions, the strongest mGluR 1 mRNA expression was found in the olfactory bulb and cerebellum, with adult cerebellum the strongest. The hypothalamus also showed a clear expression of mGluR $1 \mathrm{mRNA}$, slightly greater than that found in the hippocampus (Fig. 1).

Examination of mGluR1 protein in different brain regions with Western blots showed the receptor to be strongly expressed in the cerebellum and olfactory bulb of the adult brain (Fig. 2). The protein expression in the hypothalamus was greater than in the hippocampus, similar to the RNA results. The whole brain showed strong mGluR 1 protein expression, in part due to the robust expression of cerebellum and olfactory bulb, which were included in this sample. Liver, used as a negative control, showed no specific expression of mGluR1.

\section{Adult brain: immunocytochemistry}

mGluRl immunoreactivity was found throughout the medial and lateral (Fig. $3 A$ ) parts of the adult hypothalamus. The immunoreactive neurons extended from the rostral preoptic area back to the mammillary body. In some regions strong immunoreactivity was found, and in others the immunoreactivity was very weak. In most regions of the hypothalamus, immunoreactive cells were interspersed with neurons showing no detectable labeling (Fig. $3 \mathrm{~A}$ ). The number of immunoreactive cells varied in different regions of the hypothalamus; some regions had fewer than $1 \%$ labeled cells, and others, for instance the mammillary body, had labeling so dense that it appeared that the majority of cells were immunoreactive.

At the cellular level, the strongest staining was associated with small densities on the plasma membrane of perikarya (Fig. 4), proximal dendrites (Fig. 4), distal dendrites (Fig. 5), and sometimes on dendritic spines (Fig. $3 B$ ). Immunolabeling was found out to the ends of long dendrites reaching several hundred micrometers from the perikaryon of origin, and strong staining could be found on both distal and proximal dendrites (Fig. 5). The densities were from $0.5 \mu \mathrm{m}$ to $2 \mu \mathrm{m}$ in diameter, and strongly suggestive of a synaptic localization. No clear evidence of axonal labeling was found. A light diffuse staining was found in the cytoplasm of dendrites and cell bodies of immunoreactive cells.

In the medial hypothalamus immunolabeling was found throughout the suprachiasmatic nuclei (SCN). The staining density was so diffuse within the nucleus that it was difficult to differentiate stained cells from cells that may not have been immunoreactive. Immunoreactive cells were found in the dorsal rim of the optic chiasm ventral to the $\mathrm{SCN}$, and dendrites of these cells reached up into the SCN. Immunolabeled dendrites were found between the paired SCN. Little mGluR1 staining was found in the magnocellular neurons of the paraventricular (Fig. 6A,B) and supraoptic nuclei; weak labeling was found in the medial parvicellular paraventricular nuclei. The ventral paraventricular nucleus did show immunoreactive cells and dendrites. Similar to the neurosecretory neurons of the paraventricular nucleus, the arcuate nucleus did not show very strong immunoreactivity. Ventral to the arcuate nucleus, the median eminence, which is composed primarily of tuberoinfundibular axons, showed no labeling (Fig. 6D). Immunoreactivity was weak in the ventromedial nucleus despite the presence of long dendrites from immunoreactive cells in the regions lateral and dorsolateral to it that reached into the nucleus. The dorsomedial region of the hypothalamus showed interspersed neurons with long dendritic arbors that were immunoreactive. A strong net of dendritic arbors extended from the dorsomedial hypothalamus into the lateral hypothalamus. The fornix and mammillothalamic tracts were surrounded by immunoreactive cells and their dendrites. Immunoreactive dendrites from nearby neurons reached into these regions, but the axons of the tracts were not labeled (Fig. 3). Similarly, axons of the optic tract were not labeled (Fig. 3A).

Immunoreactive cells were dispersed throughout the preoptic area and anterior hypothalamus. Many immunoreactive cells were found in the medial preoptic area adjacent to the third ventricle and in the lateral preoptic area. Labeling was not found in the axons of the anterior commissure.

Caudally, the mammillary nuclei appeared strongly immunoreactive, with an intensity greater than rostral regions of the 


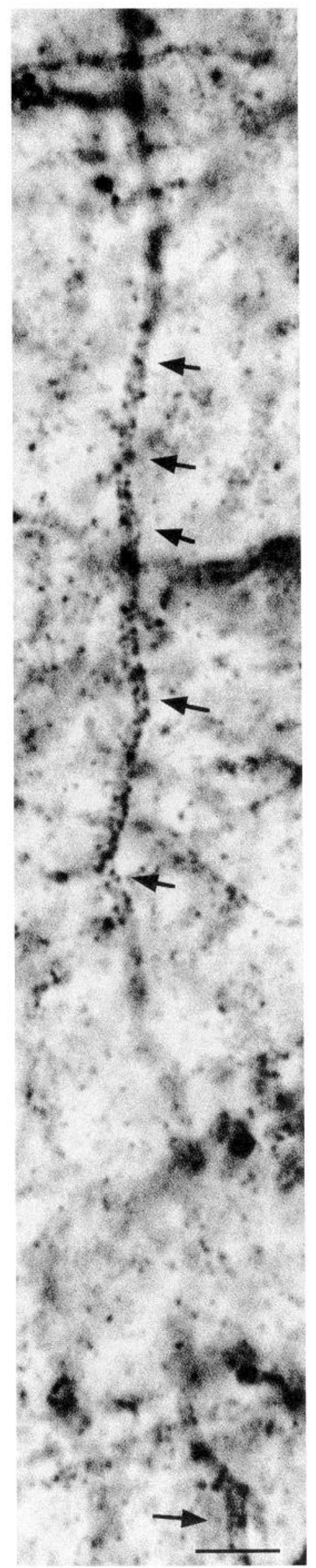

hypothalamus. This was due in large part to the large number of immunoreactive neurons and in part to the strong immunoreactivity in individual cells.

\section{Developing brain: immunocytochemistry}

Light immunoreactivity was found in the developing brain as early as day E18, the earliest time point we studied. Single differentiated cells did not stand out as they did in older animals, but some regions of the brain showed immunoreactivity, particularly an area extending down from the highly reactive globus pallidus into the lateral preoptic area.

Immunoreactivity was found in developing neurons throughout the brain by P1. Particularly striking in the medial hypothalamus was the labeling found in the SCN. Labeling was also found in the other regions that showed immunoreactivity in the adult brain. Many neurons at this early stage of development showed a morphology typical of immature neurons, and the labeling of these cells was weak. On the other hand, some neurons were strongly immunoreactive even on distal dendrites (Fig. $7 A, B$ ). Little indication of synaptic labeling was found at this stage. Rather, the immunoreactivity was more diffuse along the plasma membrane, compared to the punctate staining that was more often found in older animals.

In P7 and P9 developing brains, staining began to parallel that seen in the adult. For instance, the SCN appeared strongly labeled at all postnatal stages examined, including P1, P7, P9, P21, and adult. Similarly, the mammillary body began to express mGluR1 at P1 and this immunoreactivity increased with age. The primary change with development was the intensity and definition of labeling on single cells that appeared to increase in more mature neurons. In contrast to the SCN, the paraventricular and supraoptic nuclei consistently showed only weak labeling throughout hypothalamic development. At P7 and P9, discrete punctate regions of immunoreactivity on the plasmalemma started to appear (Fig. $7 C, D$ ). During the next 2 weeks these puncta became more numerous and the relative staining intensity increased. As in adults, these punctate densities had the appearance of being associated with synaptic specializations, as suggested in other parts of the brain with electron microscopic analyses (Martin et al., 1992).

Although we find a decrease in mGluR 1 protein levels with Western blots, this is less obvious with immunocytochemistry. The decrease in protein observed in blots may be due to a decrease in the number of cells expressing the receptor, or to a decrease in cytoplasmic receptor; neither of these decreases would necessarily be detected with immunocytochemical staining. While we cannot readily compare staining intensity with immunoperoxidase at different ages, we do observe some relative decreases in immunoreactivity in some hypothalamic regions. For instance, in the early neonatal rat the suprachiasmatic nucleus is strongly immunoreactive compared with the lateral hypothalamus on the same section. On the other hand, in adults the staining in the suprachiasmatic nucleus is relatively weak in comparison to the immunoreactive neurons of the lateral hypothalamus. The number of immunoreactive perikarya in thick vibratome sections of the hypothalamus is often obscured

Figure 5. Dendritic mGluR1. A long dendrite in the anterior hypothalamus shows immunoreactivity throughout its extent. Arrows point to the darkly stained immunoreactive densities suggestive of synaptic labeling. Scale bar, $4 \mu \mathrm{m}$. 

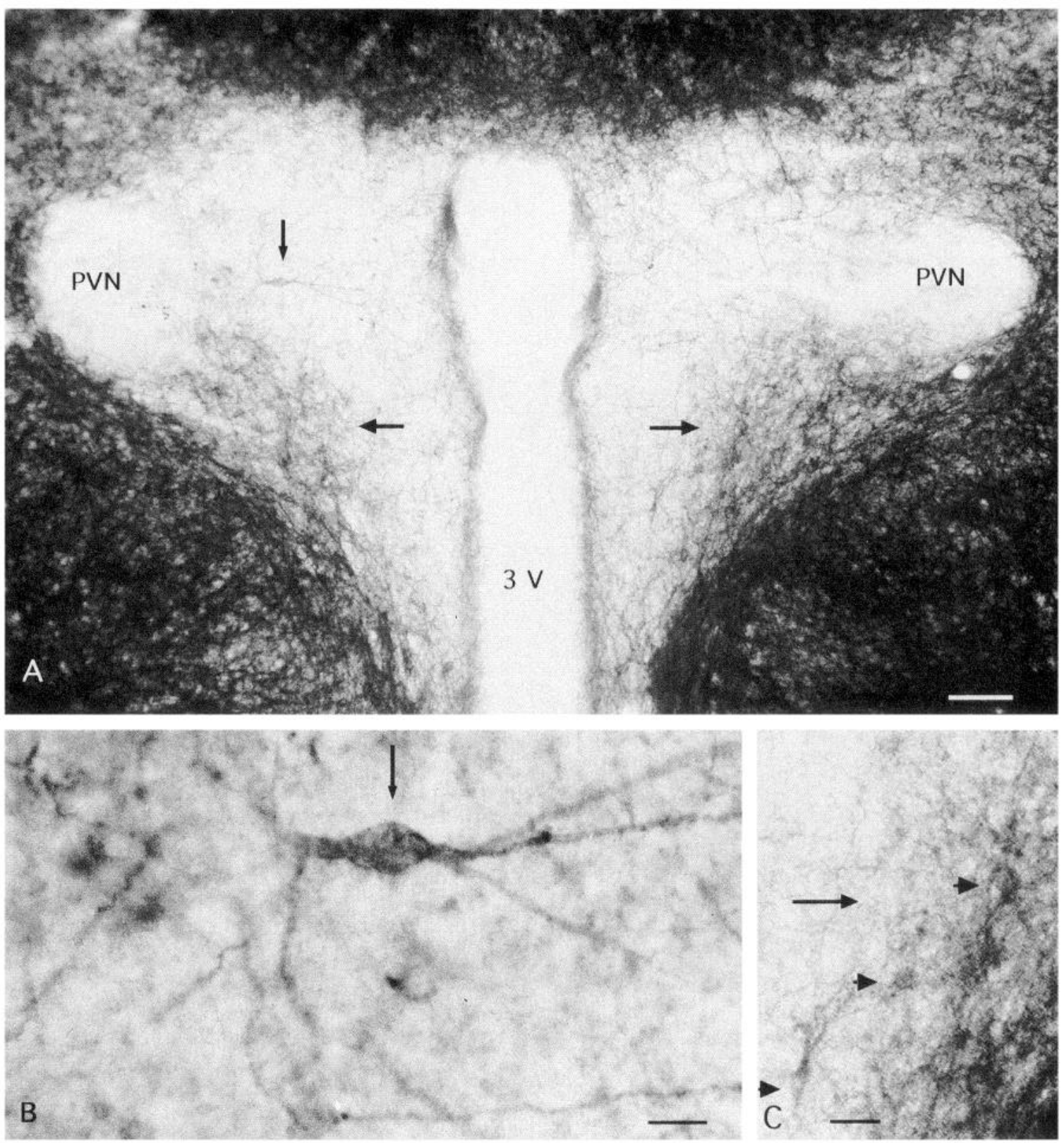

$3 \mathrm{~V}$

\section{MEDIAN EMINENCE}

D

Figure 6. Paraventricular nucleus. A, The paraventricular nucleus $(P V N)$ shows relatively few (arrows) cells immunoreactive for mGluR1, although a large number of mGluR1-immunoreactive cells surround the PVN. Immunoreactive dendrites in the ventrolateral region project into the PVN from nearby neurons outside the PVN, similar to Golgi impregnations of this hypothalamic region (van den Pol, 1982). Additionally, some neurons in this region of the PVN are immunoreactive (horizontal arrows). B. A higher magnification of the cell in $A$ indicated by the vertical arrow. A few dendrites from other cells are present in the same area. $C$, Higher magnification of immunoreactive neurons in the ventral PVN indicated by horizontal arrow. Arrowheads indicate the positions of three immunostained perikarya. $D$, The axons and cells of the median eminence show no immunoreactivity. $3 V$, third ventricle. Scale bars: $A, 120 \mu \mathrm{m} ; B, 20 \mu \mathrm{m} ; C, 40 \mu \mathrm{m} ; D, 180 \mu \mathrm{m}$. 

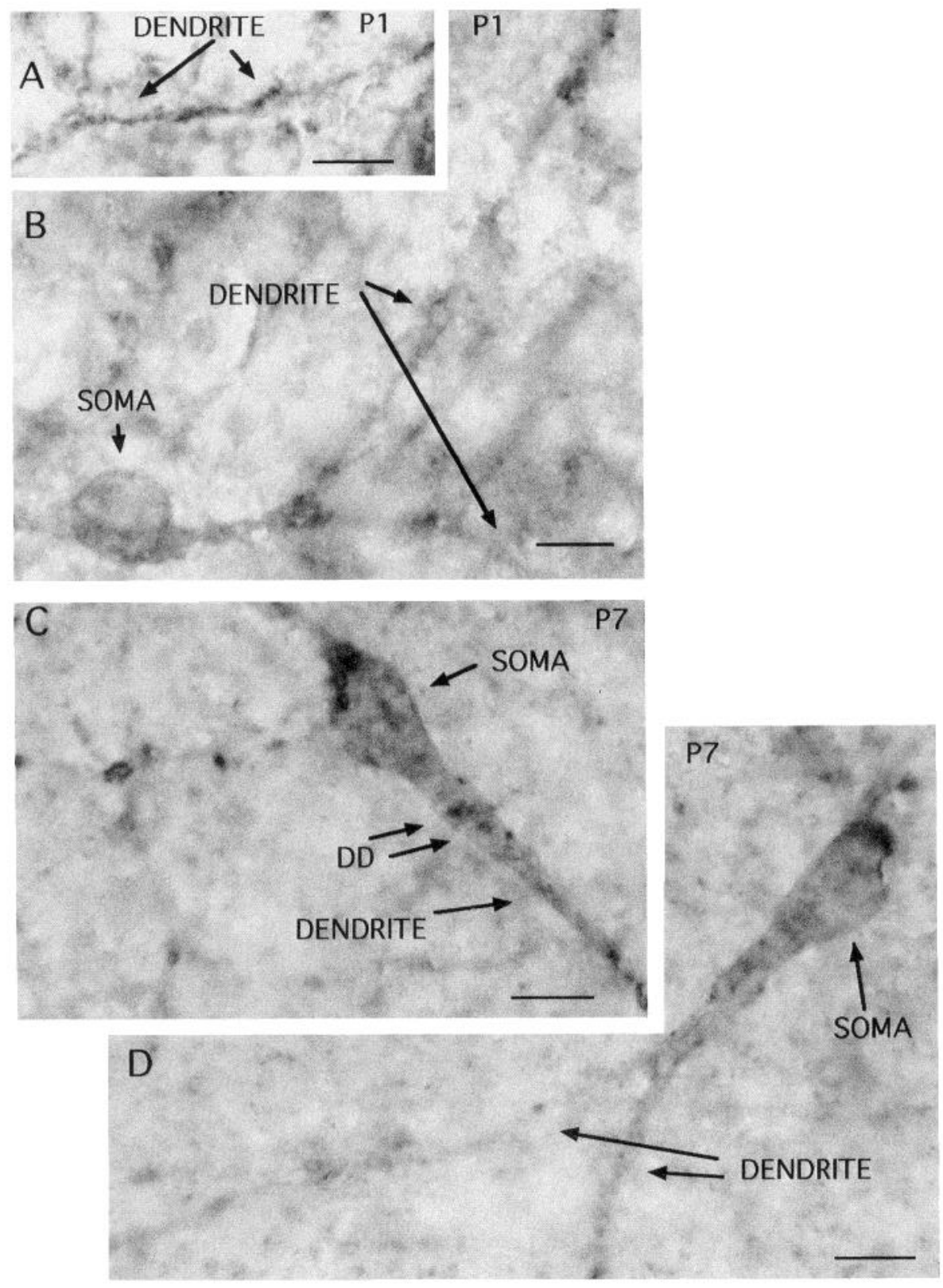

Figure 7. Cellular development of immunoreactivity. At early stages (P1) dendrites (arrows in $A$ and $B$ ) and the cell body $(B)$ show diffuse immunoreactivity. $C$ and $D$, Later in development, at P7, regions of darker immunoreactivity are seen amid a diffuse general immunoreactivity; with time these become more numerous. The small dendritic densities $(D D)$ may be early synaptic specializations. Larger densities of immunoreactivity are seen at the top of both somata, perhaps indicative of larger early synaptic contacts or congregation of receptors. Scale bars: $A, C$, and $D, 6 \mu \mathrm{m} ; B, 7 \mu \mathrm{m}$. by strong staining on high densities of dendrites, making it difficult to assess the number of immunostained cells at different developmental ages.

\section{Neurons developing in vitro: immunoreactivity}

Hypothalamic cells from E18 embryos were grown in vitro and immunostained at several intervals. After $7 \mathrm{~d}$ in vitro (DIV) a small number of cells showed strong immunoreactivity. The soma (Fig. $8 A$ ) and the dendrites (Fig. $8 A, B$ ) of immunoreactive neurons were stained. The staining in general appeared diffuse. Strong staining of astrocytes was not found. By 12 DIV the staining appeared slightly more intense (Fig. $8 C$ ). Immunoreactivity on the dendrites was found to the terminal ends of dendrites (Fig. $8 C$ ). Presumptive axons were either not labeled (Fig. $8 E$ ) or only the proximal part of the axon was labeled, and the intensity of staining decreased and then disappeared with distance from the axon hillock (Fig. 8D). By 22 DIV, punctate staining of dendrites was found (Fig. 9A). On some neurons (Fig. $9 B$ ) immunoreactive spines and dendritic appendages were found; other neurons had smooth immunoreactive dendrites lacking spines (Fig. 9C). Incubation of the antibody with the peptide antigen blocked neuronal immunostaining (Fig. 9D).

\section{Immunocytochemical controls}

To address the question of antibody specificity, we omitted the primary antiserum and found no staining. When we substituted another primary antiserum we obtained a different pattern of staining, both at the regional level and the cellular level. For instance, use of an antibody against the AMPA ( $\alpha$-amino-3hydroxy-5-methylisoxazole-4-proprionic acid) glutamate receptors that bound selectively to both GluR2 and GluR3 subunits (Blackstone et al., 1992a) gave very different patterns of staining, including a more cytoplasmic appearance in hypothalamic cells. When the mGluR1 antibody was preadsorbed with the peptide 

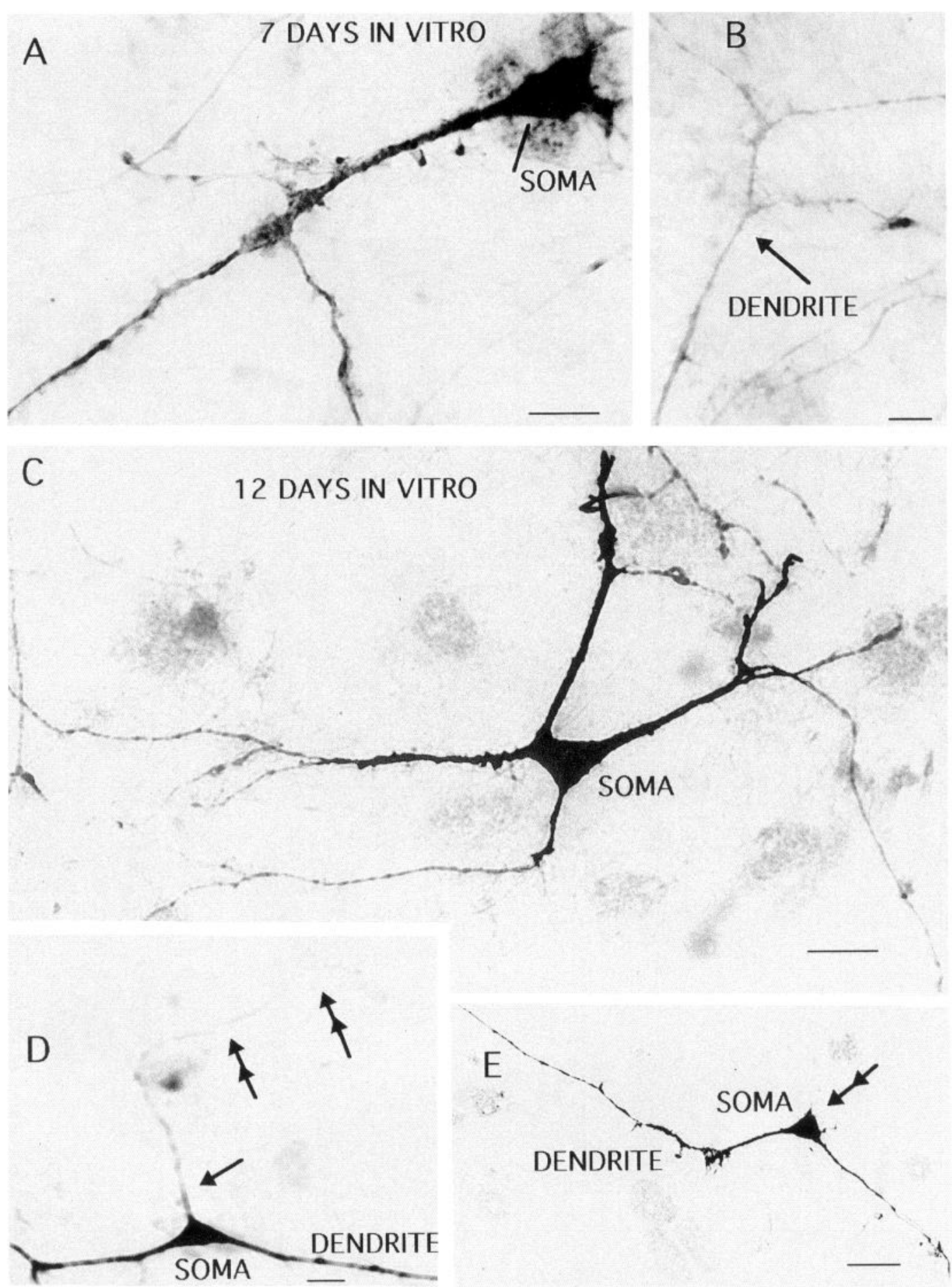

Figure 8. mGluR1 immunoreactivity in hypothalamic neurons in vitro: 7 and 12 DIV. A, After 7 DIV, soma and dendrites are stained. $B$, Immunoreactive dendrites were lightly stained at their terminal ends. $C$, At 12 DIV dendrites and the somata of reactive cells were stained. $D$. Some axons showed a slight reactivity proximally (single arrow) that diminished and was lost distally (double arrow). E, Immunoreactivity on other axons (double arrow) was not detected. Scale bars: $A, 13 \mu \mathrm{m} ; B, 3 \mu \mathrm{m} ; C, 20 \mu \mathrm{m} ; D, 11 \mu \mathrm{m} ; E, 16 \mu \mathrm{m}$.

Figure 9. mGluR1 immunoreactivity in hypothalamic neurons in vitro: 22 DIV. A, Punctate immunoreactivity (double arrow) was present on this proximal dendrite. All dendrites of this cell showed some immunoreactivity whereas underlying astrocytes showed none. $B$, Long dendritic spines and appendages (arrows) of this neuron were immunoreactive out to the distal end of the dendrites (double arrowhead). $C$, In the same culture dish as the neuron in $B$, other neurons had immunoreactive dendrites lacking any appendages. $D$, Peptide antigen adsorption controls showed no neuronal immunostaining in vitro. Scale bars: $A, 12 \mu \mathrm{m} ; B, 13 \mu \mathrm{m} ; C, 7 \mu \mathrm{m} ; D, 10 \mu \mathrm{m}$. 

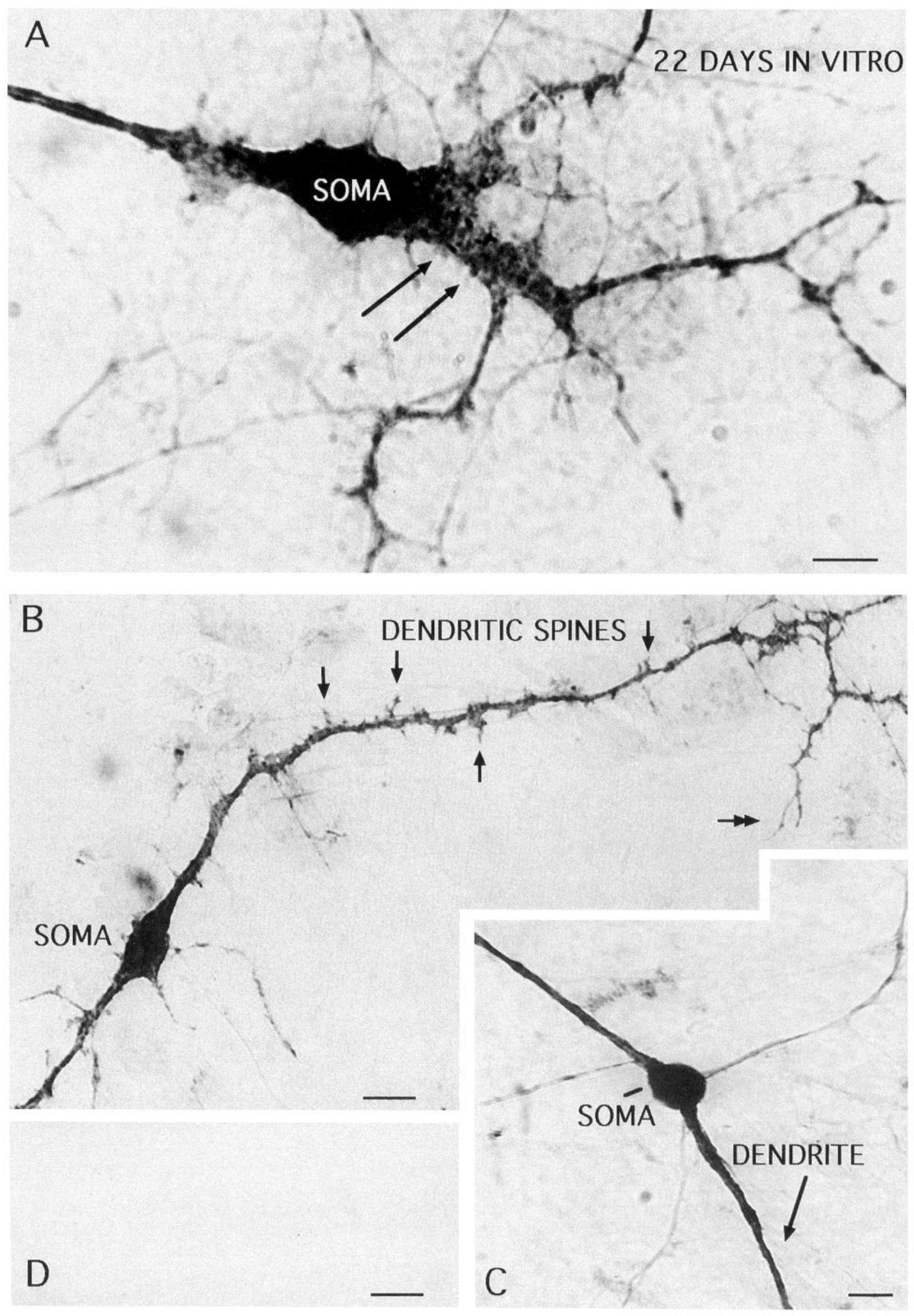


\section{MGLUR1 RNA}
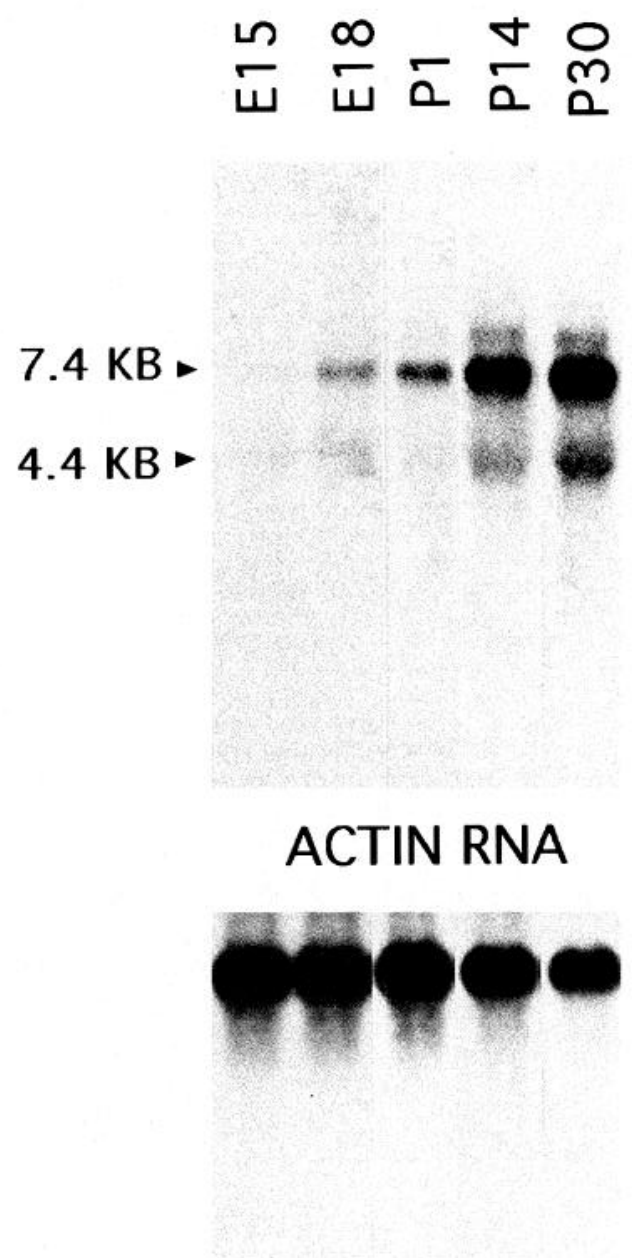

Figure 10. Developmental series of whole brain: Northern blot. A slight band indicating mGluR1 RNA is seen at E15 at $7.4 \mathrm{~kb}$, which increases in intensity through E18, P1, P14, and P30. Controls with $\gamma$-actin probes after stripping the blot show a slight decrease in RNA from the left to the right, indicating a decreased loading in successive lanes, suggesting that the relative developmental increase in mGluR1 is even greater than demonstrated in the blot above. Molecular weight markers ( 7.4 and $4.4 \mathrm{~kb})$ are indicated by arrowheads.

antigen, immunostaining was blocked throughout the hypothalamus, hippocampus, and striatum; parallel immunostaining with the antibody at the same dilution on adjacent serial sections of the same brain was positive, as expected. One exception to the total loss of staining was in the $\mathrm{SCN}$, where a faint reactivity was found after antigen adsorption; a similar light reactivity was seen in the substantia nigra after antigen adsorption. We interpret this to suggest that both areas do express mGluR 1 , but that they may in addition express some other antigen that crossreacts with the antibodies used.

Previous Western blots showed a specific staining of a band at $142 \mathrm{kDa}$ in synaptosomal preparations (Blackstone et al., 1992a; Martin et al., 1992). The Western blots in the present study were done with whole brain tissue that included both synaptosomal and cytosolic fractions. The strong staining of the $142 \mathrm{kDa}$ band of these whole brain extracts lends further support to the specificity of the affinity-purified antibodies used.

\section{Developing brain: Northern blot analysis}

Northern blots of whole brain RNA extracts were compared at different stages of development (Fig. 10). A very slight hybridization with the mGluR1 probe was detected at E15 that was clearly seen by E18. This increased at P1 and was very strong by P14. Only a slight increase from P14 to P30 was found. Actin controls used to check on gel loading showed that, if anything, less RNA was loaded from older animals, thus confirming the general relative increase in $\mathrm{mGluR} 1$ expression. Different regions of the brain were studied in a time series analysis of Northern blots (Fig. 11). At all ages, including P1, P10, P20, and adults, the cerebellum showed the strongest RNA expression, and the olfactory bulb also showed a strong expression. Faint bands at the expected size for mGluR1 $(7.4 \mathrm{~kb})$ were seen as early as E18 in hypothalamus, olfactory bulb, and cortex. By P1 strong bands were found in all regions studied at 7.4 and $4.4 \mathrm{~kb}$, similar to the two bands reported by Masu et al. (1991) and Bessho et al. (1993). These bands are considered to be from the same gene, as different inserts from the mGluR 1 cDNA hybridize consistently with both bands (Masu et al., 1991).

\section{Developing brain: Western blot analysis}

Levels of mGluR 1 protein were studied in the developing whole brain with Western blots. A general developmental increase in mGluRl protein from embryonic to adult brains was found relative to total protein (Fig. 12A).

To examine the expression of mGluR 1 protein in discrete brain regions, particularly in the hypothalamus in comparison to other regions including the hippocampus and cerebellum, protein extracted from E18, P1, P9, P15, and adult was compared (Fig. 12B). The intensity of the mGluR1 band was strongest in the cerebellum at all times tested, and showed a gradual increase from P1 to adult. At early stages of development, the hypothalamus showed a greater expression of mGluR 1 protein than the hippocampus. In the hypothalamus a gradual increase in mGluR 1 was found, with expression detectable at E18 and increasing at P7-P15. In adult brains a slight decrease in mGluR1 relative to total protein was found in hypothalamus in comparison with younger brains.

\section{Calcium imaging}

In Western and Northern blots, little mGluR1 RNA or protein is detectable at embryonic ages. To address the question of functional maturity of the metabotropic glutamate receptor in young developing neurons from embryonic brains, and to establish that the receptor in these immature neurons is actively coupled with $\mathrm{G}$ protein such that a $\mathrm{Ca}^{2+}$ response can be elicited by receptor activation, we examined hypothalamic cultures taken from E18 embryos and kept in vitro for 2-4 d (Fig. 13). We found that these cells $(95 \%+, n>300)$ responded to glutamate with an increase in intracellular $\mathrm{Ca}^{2+}$. Increases in $\mathrm{Ca}^{2+}$ in these experiments could be due to activation of the NMDA receptor, some of the AMPA receptors (Hollmann et al., 1991; Hume et al., 1991; Verdoorn et al., 1991), or to metabotropic receptors (Furuya et al., 1989).

Acute exposure of cultured cells to the nonselective metabotropic glutamate receptor agonist quisqualate $(10 \mu \mathrm{M})$ increased intracellular $\mathrm{Ca}^{2+}$ in both neurons and astrocytes (Fig. 14). Of 163 cells, 102 neurons responded to NMDA. Of these, a response to quisqualate was detected in 10 neurons. Of 66 cells with a morphology typical of astrocytes, 51 responded to 

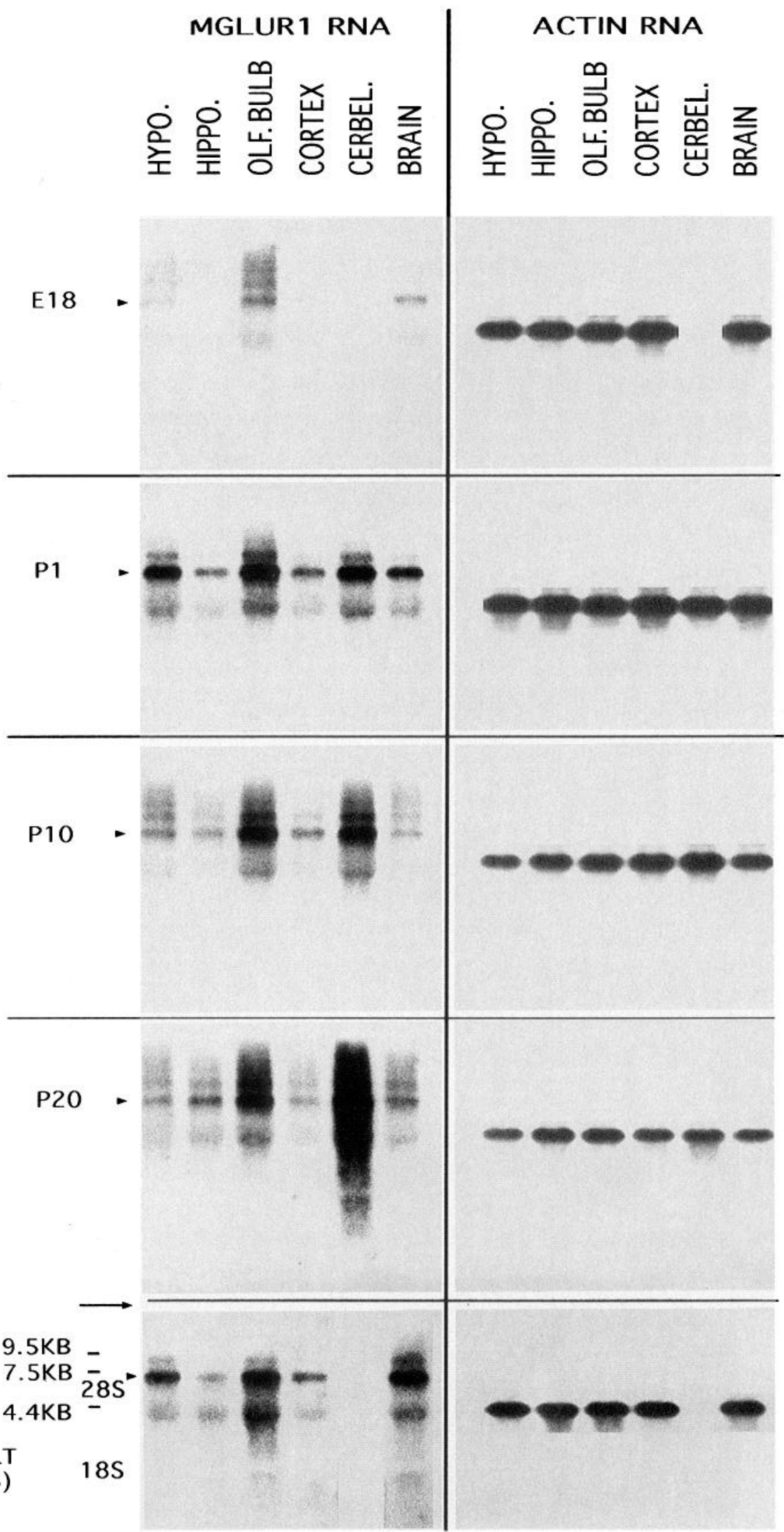

Figure 11. Regional developmental series: Northern blot. Hypothalamus (HYPO.), hippocampus (HIPPO.), olfactory bulb $(O L F . B U L B)$, cortex, cerebellum (CERBEL.), and brain were compared at E18, P1, P10, P20, and adult. Molecular sizes were determined using RNA ladders from Bethesda Research Labs and Boehringer Mannheim run on the same gel. mGluR 1 is shown in the left column. The $28 \mathrm{~S}$ and $18 \mathrm{~S}$ ribosomal RNA species are shown at the bottom relative to the adult series. The $7.4 \mathrm{~kb}$ mGluR1 RNA bands are shown at the left of each group with an arrowhead. A long arrow in the adult series shows the origin. In the right column are the same brain regions as shown on the left after stripping and rehybridizing the blot with a $\gamma$-actin probe, used to verify similar loading concentrations of RNA. All brain regions were run on the same gel, and blotted simultaneously. The cerebellum lane for E18 was not run; the cerebellum lane in the adult is missing as preliminary work showed that the amount of mGluR1 RNA was sufficiently great at that age that the signal bled over into adjacent lanes. Another blot with less RNA showed the adult cerebellum RNA signal to be the highest of all brain regions. The bands at P1 appear stronger than at P10. This may be due to the greater amounts of RNA loaded in the P1 series, as judged by the relative staining of actin controls for P1 and P10. 


\section{DEVELOPMENTAL EXPRESSION OF MGLUR1 PROTEIN}

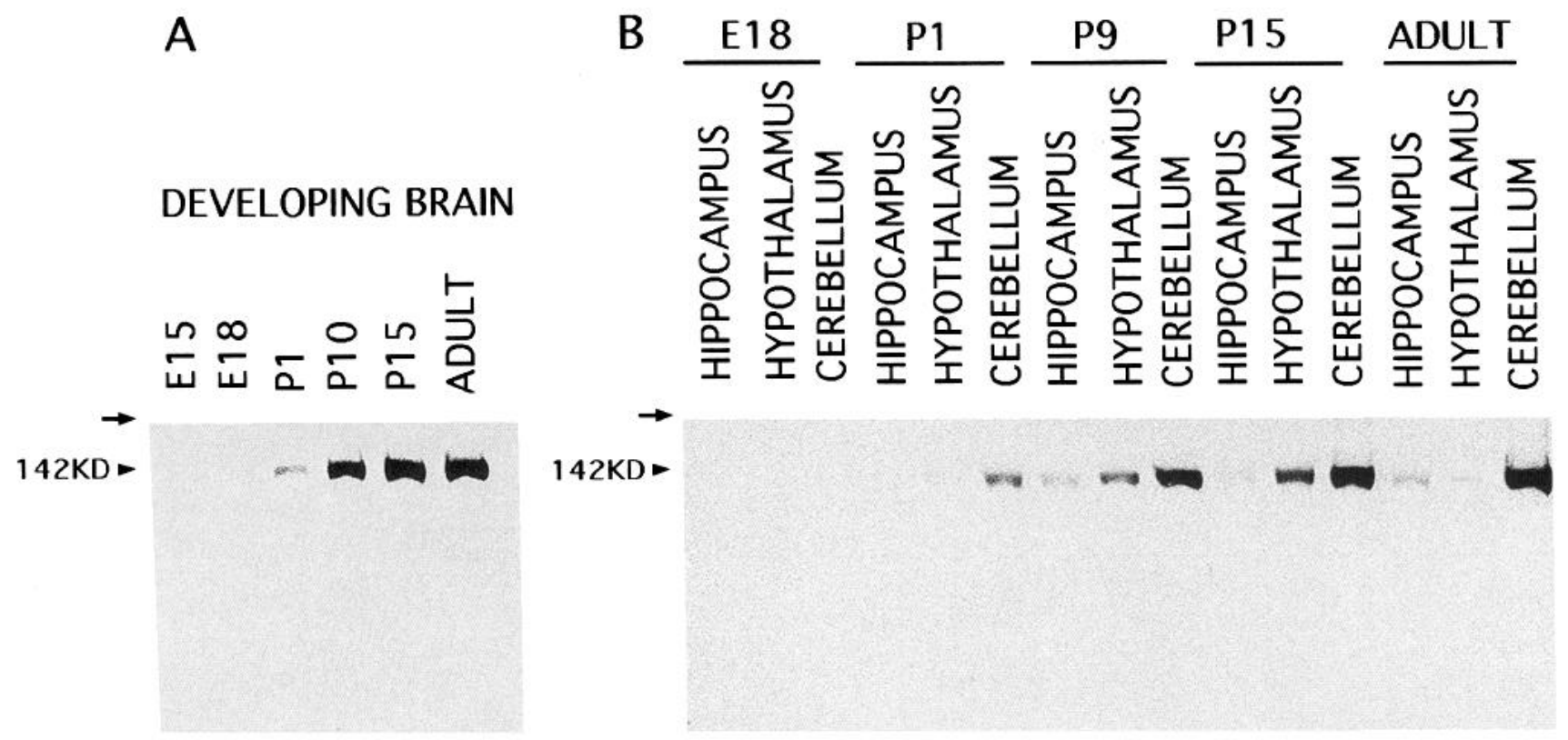

Figure 12. Developmental regulation of mGluR1: Western blot. $A$, During development a modest expression of mGluR1 protein was found in whole brain at P1; this increased dramatically by P10 and P15. Expression in adult whole brain was slightly greater than at the other ages. $B$, To follow the mGluR 1 expression in selected brain regions, we compared hypothalamus with hippocampus and cerebellum. Lanes are shown in a developmental grouping, with the age indicated at the top. Little detectable mGluR1 protein was found at E18, but a slight reactivity was found at P1, particularly in the cerebellum, and less in the hypothalamus. By P9 stronger labeling was seen in all three regions, with the greatest signal in the cerebellum. An increase in staining was found in the hypothalamic and cerebellar bands at P15. However, in adults, the hypothalamic and hippocampal bands were less intense than those seen in neonatal ages, whereas the cerebellum band showed the strongest intensity of any age. These experiments were run in duplicate with relatively similar results found in each run. The arrowhead represents $142 \mathrm{kDa}$, and the arrow at the top of the blot shows the origin.

quisqualate and none responded to NMDA. Because quisqualate may activate ionotropic glutamate receptors in addition to metabotropic receptors, we used the weaker but more selective metabotropic receptor agonist t-ACPD (trans-1-amino-cyclopentyl-1,3-dicarboxylic acid). About $20 \%$ of the total cells (11 of 50) including glia and neurons responded to application of $\mathrm{t}$-ACPD. Three of 30 neurons responded to $100 \mu \mathrm{m} \mathrm{t}-\mathrm{ACPD}$
(Fig. 15). Astrocytes ( 8 of 20 ) in the same culture dish also responded to t-ACPD, but none responded to NMDA. To demonstrate that the cells that responded were neurons and not other types of cells, we stimulated the cells with NMDA. Only cells with a morphology typical of cultured neurons responded to NMDA. Fewer astrocytes responded to t-ACPD than to quisqualate.
Figure 13. Hypothalamic neurons cultured from E18 rats were loaded with the $\mathrm{Ca}^{2+}$ indicator dye fluo 3 after 3 DIV, and stimulated with $10 \mu \mathrm{M}$ quisqualate. These cells are typical of hypothalamic cultures at this stage of development. Scale bar, $18 \mu \mathrm{m}$.

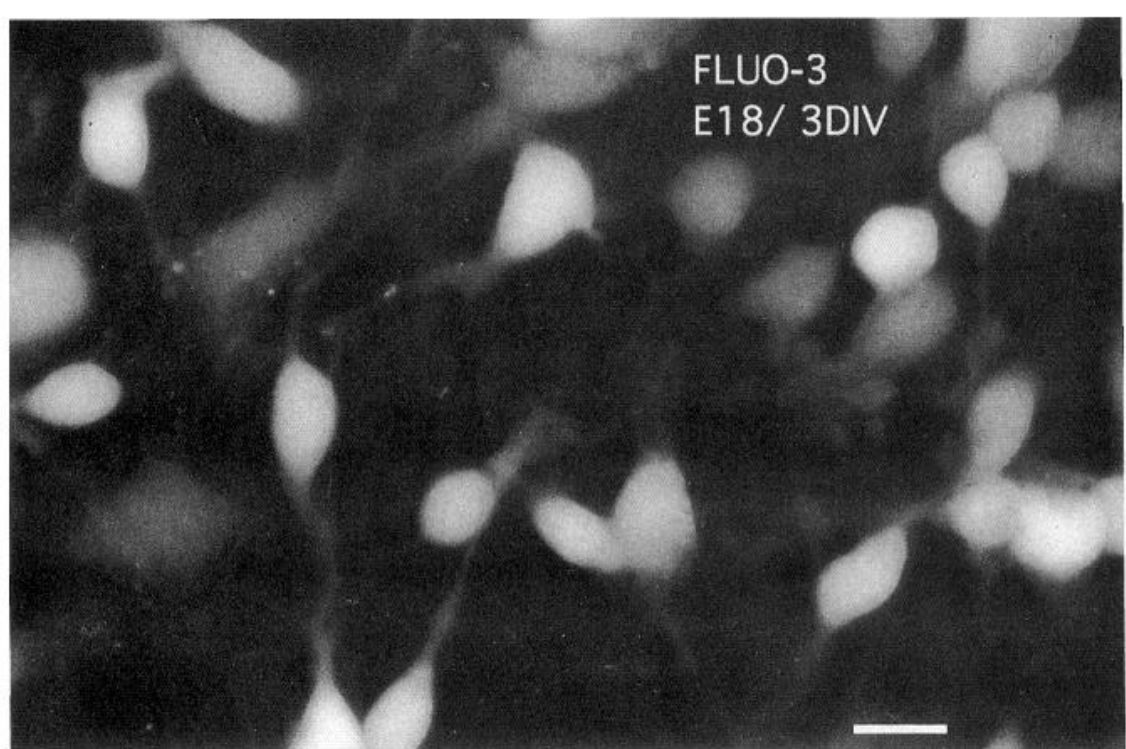


To determine if a longer duration in culture would increase the number of neurons that responded to metabotropic glutamate receptor agonists, we examined E1 8 hypothalamic neurons after 5 or $6 \mathrm{~d}$ in culture. Of 55 neurons that responded to NMDA, $14(21 \%)$ of these also responded to application of t-ACPD. Of the 55 neurons, $37(67 \%)$ responded to quisqualate. If the percentage of neurons that responded at earlier times is compared with the number that responded at a later time in culturc, the number of cells that responded to $t$-ACPD doubled. The number of cells that responded to quisqualate increase by almost a factor of 7 .

The ionotropic receptors increase intracellular $\mathrm{Ca}^{2+}$ by opening channels in the external plasma membrane. In contrast, an increase in intracellular $\mathrm{Ca}^{2+}$ in the absence of extracellular $\mathrm{Ca}^{2+}$ must originate from intracellular stores. Such release has been characterized after activation of metabotropic glutamate receptors that stimulate phospholipase $\mathrm{C}$, resulting in $\mathrm{IP}_{3}$ production. Stimulation of E18 neurons after $3 \mathrm{~d}$ in culture with glutamate $(100 \mu \mathrm{m})$ in the absence of extracellular $\mathrm{Ca}^{2+}$ produced an increase in intracellular $\mathrm{Ca}^{2+}$ in two of 41 neurons that also responded to NMDA in the presence of extracellular $\mathrm{Ca}^{2+}$ (Fig. 16). Since neurons respond to NMDA and astrocytes do not, those cells that respond both to NMDA (in the presence of extracellular $\mathrm{Ca}^{2+}$ ) and to glutamate (in the absence of extracellular $\mathrm{Ca}^{2+}$ ) are neurons that express both ionotropic NMDA and metabotropic glutamate receptors. Ten additional cells had the general appearance of neurons, but did not respond to NMDA. Of 27 cells with the appearance of astrocytes, 21 responded to glutamate in the absence of extracellular $\mathrm{Ca}^{2+}$ (Fig. 16).

\section{Discussion}

Two related aspects of the glutamate metabotropic receptor mGluR 1 are explored here. In the first, we examine the widespread but heterogeneous expression of the receptor throughout the hypothalamus. Having demonstrated mGluR 1 in the hypothalamus, we then explore the complex developmental regulation of this receptor, examining RNA levels as a window on gene expression, investigating protein expression to study the distribution of the translated message, and studying the $\mathrm{Ca}^{2+}$ response with digital imaging to determine the functional maturity of the receptor in developing neurons.

\section{Hypothalamic expression of $m G l u R 1$}

In the adult hypothalamus, widespread expression of mGluR 1 was found, with levels similar to or greater than those in the hippocampus, a region of the brain more traditionally associated with glutamate neurotransmission. Based on immunocytochemistry, the high levels of mGluR 1 in the mammillary body and lateral regions of the hypothalamus contributed a large part of the total. The mediobasal region showed the weakest expression of mGluR 1 within the hypothalamus, both in adults and in the developing brain.

Together with previous work demonstrating the expression of the NMDA, kainate, and AMPA receptor subtypes (van den Pol et al., in press), the present study supports the general concept that glutamate plays a complex role in hypothalamic regulation. In addition to the diverse physiological actions of each of the individual ionotropic and metabotropic glutamate receptors, the metabotropic receptor may interact with and regulate glutamate (and GABA) ionotropic receptors in some regions of the brain (Glaum and Miller, 1993). Conversely, NMDA re-
NEURON Ca2+ RESPONSE TO QUISQUALATE
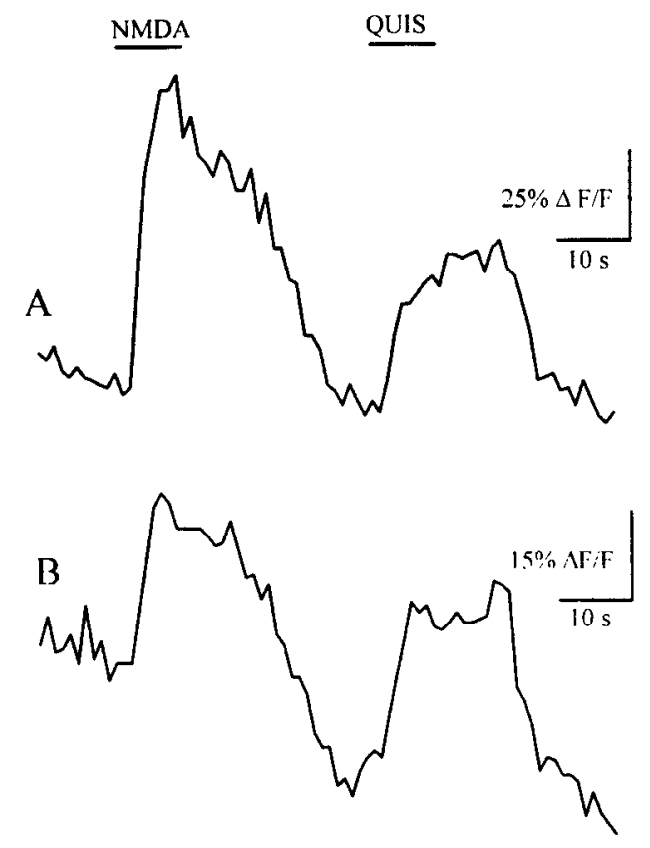

ASTROCYTE Ca2+ RESPONSE TO QUISQUALATE

QUIS
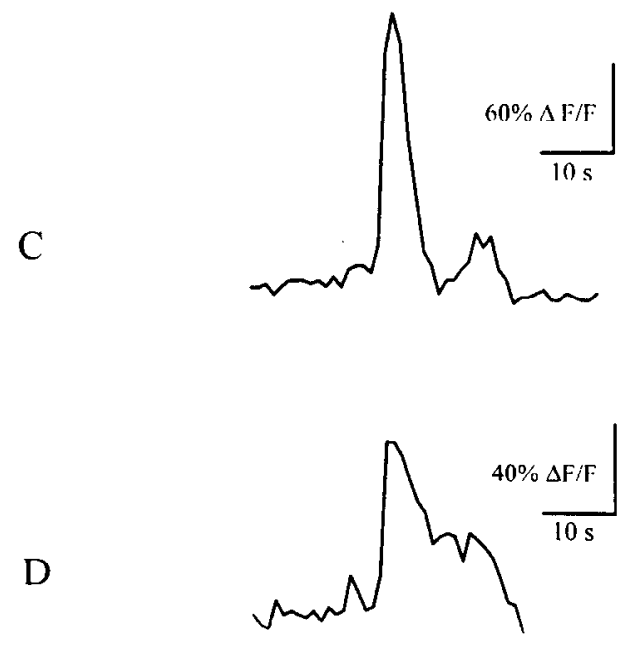

Figure 14. $\mathrm{Ca}^{2+}$ response of hypothalamic neurons to quisqualate. Two neurons $(A$ and $B$ ), identified by their response to a $10 \mathrm{sec}$ application of $100 \mu \mathrm{M}$ NMDA, also respond to $10 \mu \mathrm{M}$ quisqualate. Astrocytes $(C$ and $D)$ also respond to quisqualate with an increase in intracellular $\mathrm{Ca}^{2+}$. Data are graphed as the change in fluorescence over baseline fluorescence $(\Delta F / F)$, shown by the vertical calibration, and time in seconds, by the horizontal calibration (Cornell-Bell et al., 1990; Finkbeiner, 1991, 1992). A delay of about 6 sec occurs between the time the agonists are changed and when they reach the cells in the perfusion chamber.

ceptor activation may reduce phosphotidylinositol hydrolysis induced by the metabotropic glutamate receptor (Palmer et al., 1990). The metabotropic receptor has been reported to decrease ionotropic receptor-mediated excitotoxicity in the retina (Sili- 


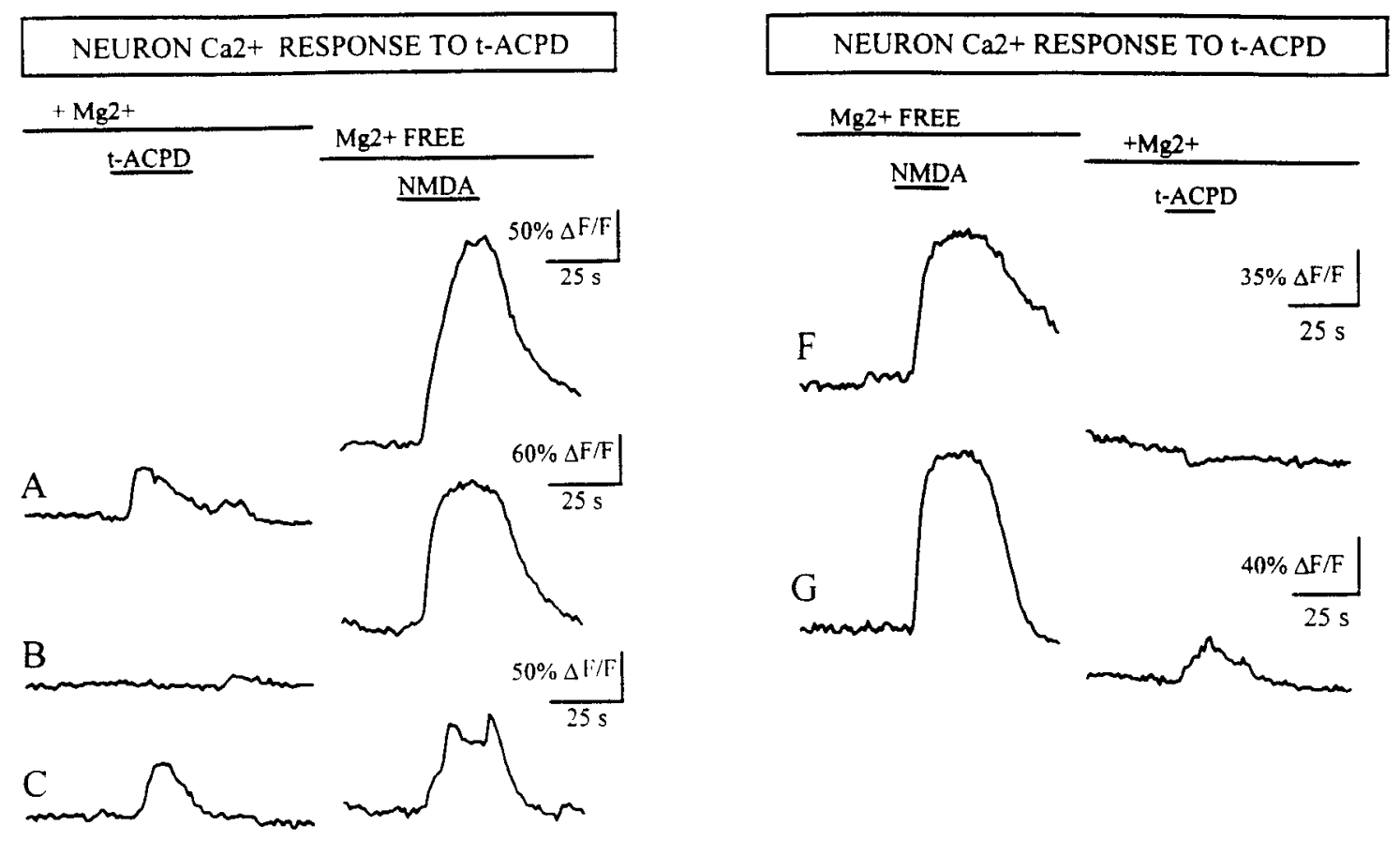

\section{ASTROCYTE Ca2+ RESPONSE TO t-ACPD}
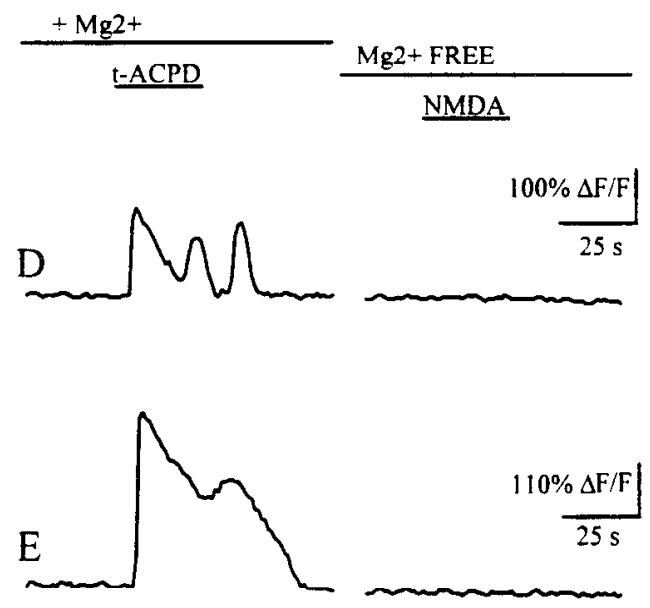

ASTROCYTE Ca2+ RESPONSE TO t-ACPD

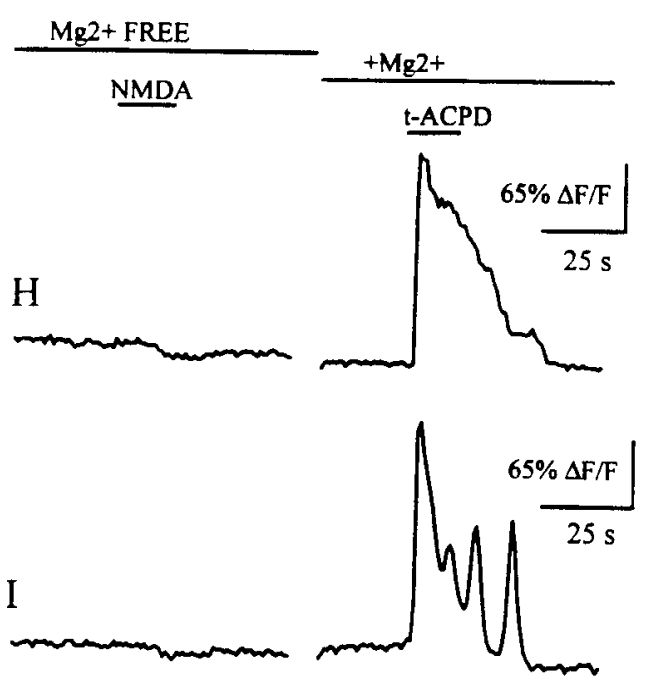

Figure 15. $\mathrm{Ca}^{2+}$ response of hypothalamic neurons to t-ACPD. Neurons $A$ and $C$ show a $\mathrm{Ca}^{2+}$ increase in response to $100 \mu \mathrm{M}$-ACPD. At this concentration t-ACPD should not activate ionotropic receptors (Shoepp et al., 1990). Upon changing the buffer to one free of $\mathrm{Mg}^{2+}$, an increase in fluorescence is found. That these cells are neurons is supported by the increase in $\mathrm{Ca}^{2+}$ in response to $100 \mu \mathrm{M}$ NMDA. A similar modest response to $100 \mu \mathrm{M} \mathrm{t}$-ACPD is found when the order of agonist perfusion is reversed, as seen in neuron $G$. Neurons $B$ and $F$ show no $\mathrm{Ca}^{2+}$ increase in response to t-ACPD, although they both respond to $100 \mu \mathrm{M}$ NMDA. Part of the increase in $\mathrm{Ca}^{2+}$ upon removal of $\mathrm{Mg}^{2+}$ from the buffer may be from release of transmitter glutamate from neurons in the culture dish. This would tend to increase intracellular $\mathrm{Ca}^{2+}$ via the unblocked NMDA receptor, as reported previously (van den Pol and Trombley, 1993). In the same dish as neurons $A-C$, astrocytes $D$ and $E$ respond to t-ACPD, but not to NMDA. Similarly, when the order of perfusion is reversed, astrocytes $H$ and $I$ in the same dish as neurons $F$ and $G$ do not respond to NMDA, but do respond to t-ACPD. Astrocyte $I$ shows the start of an oscillation, and astrocyte $H$ shows a peak that decreases over about 35 sec.

prandi et al., 1992) and to increase excitotoxicity in the striatum (McDonald and Schoepp, 1992). These interactions between the receptor subtypes further increase the complexity of the potential responses of hypothalamic neurons to glutamate.

An important excitatory afferent input to the hypothalamus is the retinal projection to the suprachiasmatic nucleus (van den
Pol and Dudek, 1993). That this is a glutamatergic pathway is supported by findings that immunoreactive glutamate is found in high concentrations in presynaptic retinal boutons (Castel et al., 1993), optic nerve stimulation releases glutamate (Liou et al., 1986), and the response of SCN cells to optic nerve stimulation can be blocked by the glutamate receptor antagonists 
kynurenic acid and CNQX (Cahill and Menaker, 1989; Kim and Dudek, 1992). That the mGluRl immunoreactivity we find in the SCN in the present study represents functional metabotropic receptors is confirmed by confocal laser $\mathrm{Ca}^{2+}$ imaging studies on cultured developing SCN neurons (Bina et al., 1993). Because glutamate may be an important transmitter inducing phase changes in the circadian clock, the glutamate receptors postsynaptic to the retinal input would therefore play an important role in long-term changes in circadian ciock function. The contribution of the glutamate metabotropic receptor to phase alterations induced by release of retinal glutamate has not yet been examined.

Neuroendocrine neurons in the paraventricular and supraoptic nuclei project to the neurohypophysis and release oxytocin and vasopressin, and those in the arcuate nucleus release pituitary tropins in the median eminence. Glutamate may be released as a primary excitatory transmitter in afferent projections to these neurosecretory neurons, and the predominant type of ionotropic glutamate receptor appeared to be non-NMDA receptors (Gribkoff and Dudek, 1990; van den Pol et al., 1990; Wuarin and Dudek, 1991), although NMDA receptors are also expressed by these cells (Gribkoff, 1991; Hu and Bourque, 1992; van den Pol et al., 1994). In contrast, we find little mGluR 1 expression in neuroendocrine cells in the present report. Although a few scattered cells can be found near the magnocellular neurosecretory systems, the number of immunoreactive neurons is smaller than in other regions of the hypothalamus, suggesting a negligible contribution of $m$ GluR 1 to the glutamate response of neuroendocrine neurons. On the other hand, in regions of the paraventricular nucleus that have been shown to project not to the pituitary but instead to the midbrain and spinal cord (Armstrong et al., 1980; Swanson and Kuypers, 1980), cells do express mGluR1. This indicates a significant difference probably exists in the response to glutamate between neurosecretory neurons (that project to the hypophysis) and non-neurosecretory neurons (that project to other regions of the CNS).

\section{Developmental changes}

As early as E18 we found evidence that mGluR1 RNA was expressed by hypothalamic neurons, and that this expression was much greater by P1. In Western blots, protcin was difficult to detect before P1. However, at P1 mGluR1 protein was detected as a strong protein band; in parallel studies stained individual cells could be seen with immunocytochemistry. That the receptor was functionally active in immature hypothalamic neurons is supported by the series of physiological experiments; digital $\mathrm{Ca}^{2+}$ imaging indicated that cells cultured from E18 embryos and allowed to recover for $3 \mathrm{~d}$ responded to both the nonspecific metabotropic receptor agonist quisqualate and to the more selective agonist $\mathrm{t}-\mathrm{ACPD}$. The $\mathrm{Ca}^{2+}$ rise seen with activation of the metabotropic receptor shows the receptor is functionally coupled to its second messenger effector mechanism even at early stages of neuronal development. This is at a time when immunostaining with mGluR 1 antiserum of neurons in vivo or in vitro demonstrates a lack of the punctate staining characteristic of synaptic specialization seen in mature immunoreactive neurons.

That cells showed a cytoplasmic increase in $\mathrm{Ca}^{2+}$ in the $\mathrm{ab}$ sence of extracellular $\mathrm{Ca}^{2+}$ lends further credence to the specific activation of a receptor that stimulates release of $\mathrm{Ca}^{2+}$ from intracellular stores. Three days of neuronal growth in culture

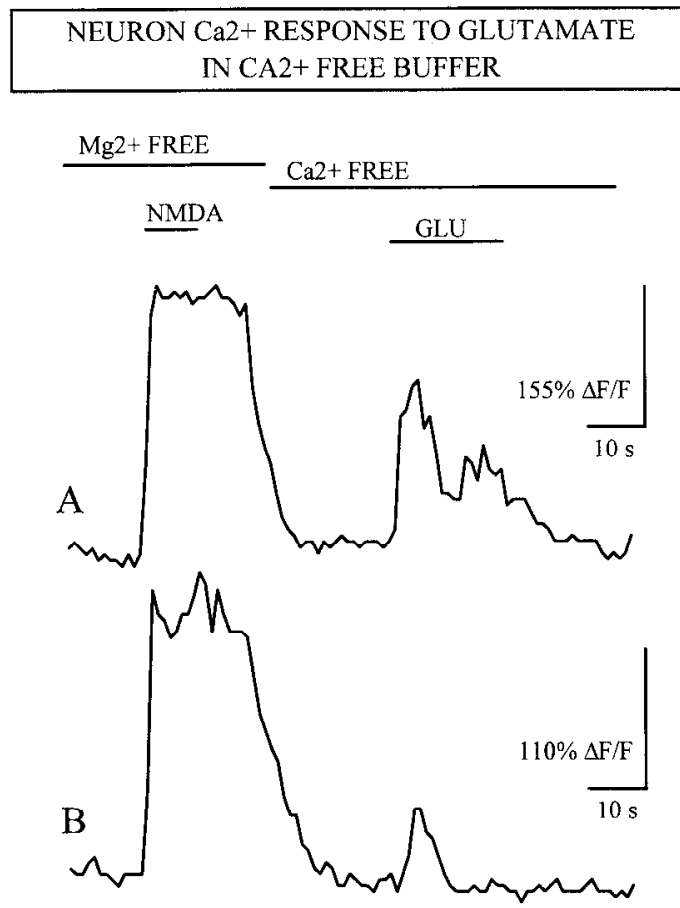

ASTROCYTE Ca2+ RESPONSE TO GLUTAMATE IN CA2+ FREE BUFFER

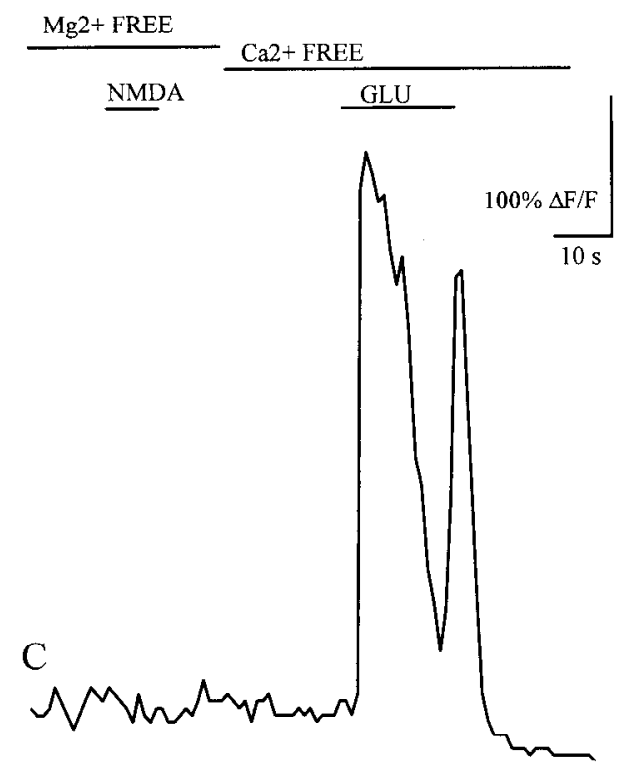

Figure 16. $\mathrm{Ca}^{2+}$ response of hypothalamic neurons to glutamate in the absence of extracellular $\mathrm{Ca}^{2+}$. Two neurons $(A$ and $B)$ show a strong response to the application of $100 \mu \mathrm{M}$ NMDA in the presence of extracellular $\mathrm{Ca}^{2+}$ and the absence of $\mathrm{Mg}^{2+}$, and also show an increasc in intracellular $\mathrm{Ca}^{2+}$ in response to $100 \mu \mathrm{M}$ glutamate in $\mathrm{Ca}^{2+}$-free conditions. An astrocyte $(C)$ does not respond to $100 \mu \mathrm{M}$ NMDA, but does respond to glutamate in $\mathrm{Ca}^{2+}$-free buffer. The astrocyte shows the beginning of an oscillation that disappears in the absence of glutamate. Continued application of glutamate (not shown) leads to $\mathrm{Ca}^{2+}$ oscillations in a number of astrocytes. 
may not parallel $3 \mathrm{~d}$ of normal development in situ; development of cultured cells may be retarded in vitro as neuritic processes that may have started to grow in vivo prior to the culturing procedure would have to regrow and differentiate to catch up with the course of normal development. A primary point here is that some embryonic neurons after short durations in culture show evidence of functional metabotropic glutamate receptors. The relative number of cells that showed detcctable metabotropic responses was small, particularly in contrast to the large percentage that responded to NMDA. The relatively large number of neurons responding to NMDA may in part have been due to a greater magnitude of the intracellular $\mathrm{Ca}^{2+}$ response to NMDA stimulation compared with metabotropic receptor stimulation, making detection of a response to NMDA more likely. With time in culture, more neurons express metabotropic receptors in numbers sufficient to be detected with the functional $\mathrm{Ca}^{2+}$ assay we used.

Neurons grown in vitro showed a developmental sequence of staining similar to that found in vivo. However, in vitro developmental expression of the punctate densities appeared retarded compared with their appearance in vivo. If the punctate densities on dendrites are related to synaptic junctions, then the slower development of immunoreactivity in these subcellular regions is probably due to the small number of afferent axons innervating the neurons in culture. The functional expression of mGluR1 precedes the primary course of hypothalamic synaptogenesis. Although the amounts of protein and RNA coding for mGluR 1 were at low levels in the embryonic brain, the $\mathrm{Ca}^{2+}$ imaging experiments showed that some neurons did express functional metabotropic receptors at early ages, at a time when the receptor was not clustered at possible synaptic junctions, as shown by immunocytochemistry. In parallel, a large number of hypothalamic astrocytes showed physiological responses indicative of the presence of the metabotropic receptor. With immunocytochemistry, all the strongly labeled cells studied in hypothalamic sections had the morphology of neurons, similar to other parts of the brain (Martin et al., 1992). It is probable that the functional metabotropic receptor expressed by astrocytes as detected with $\mathrm{Ca}^{2+}$ imaging, and possibly some of the metabotropic response seen in neurons, may be due to a metabotropic receptor other than $m$ GluR 1 . A number of other metabotropic receptors have been cloned (Abe et al., 1992; Tanabe et al., 1992), and at least one, mGluR5, has physiological properties similar to mGluR 1 (Nakanishi, 1992). Astrocytes in some regions of the brain have been reported to express mGluR5 (Abe et al., 1992). Alternatively, a small number of mGluR 1 receptors may not be detected with protein blots, particularly if expressed by only a small number of cells, but may still underlie physiological responses to glutamate.

A number of previous reports have suggested that neurons in some regions of the brain show a stronger phosphotidylinositol response to glutamate during development than in the mature brain (Palmer et al., 1990; Sortino et al., 1991). Our results with Western blots suggest that at least part of this decrement in response is due to a reduction in $\mathrm{mGluR} 1$ protein in the adult brain. Interestingly, our developmental Northern blots do not show such a dramatically decreased RNA expression in either total brain or in the hypothalamus. These data suggest that mGluR 1 RNA levels may not necessarily predict protein expression, and that brain-region-specific regulatory mechanisms may be operating at the translational level. The results found in the hypothalamus could reflect either a decreased level of translation, or accelerated degradation of $\mathrm{mGluR} 1$ protein in the adult compared with the P9 stage. There is evidence that receptors involved in $G$ protein signaling, such as the metabotropic receptors, may have a rapid turnover (Bessho et al., 1993), pointing to protein degradation rate as an important regulatory mechanism. The relative reduction in hypothalamic protein and the absence of such a reduction in cerebellar protein and RNA in our studies are consistent with earlicr studies that found a developmentally regulated reduction of physiological response of metabotropic receptors in the former area, and little reduction in the cerebellum (Balduini et al., 1991; but see Palmer et al., 1990). In addition to the reduction of protein as described in the present report, other mechanisms related to coupling of the metabotropic receptor with $G$ proteins, or possible interactions of the metabotropic receptor with developing ionotropic glutamate receptors, may also contribute to the developmental decrease in metabotropic receptor activity. In contrast, some $G$ protein-coupled receptors may become more active in adults, as suggested for the muscarinic receptor in cortex (Heacock et al., 1987).

These data underscore the differential regulation of the same glutamate receptor subtype by neurons from different brain regions. Part of the increase in $\mathrm{mGluR} 1$ in the cerebellum may be due to the late (P7) final mitosis and migration of granule cells in the cerebellum. Granule cells, although small, constitute a very large number of cells, and they develop much later than cells of the hypothalamus. The granule cells also provide the major excitatory input to the Purkinje cells that express high levels of mGluR1. The increase in mGluR 1 expression found in whole brain of adults relative to neonatal animals is in part due to the very strong expression of mGluR 1 in the cerebellum.

In contrast to the reduction in protein found with $\mathrm{mGluR} 1$ antibody staining of Western blots in adult hypothalamus, there are still a large number of cells in the adult hypothalamus that show immunoreactivity with the same antibodies. This suggests that despite the general decrease in total mGluR 1 protein relative to RNA in the hypothalamus, protein is still expressed by some hypothalamic neurons. The immunostaining on individual cells studied microscopically does not appear less on adult cells than it does on neonatal cells, although quantitative evaluations based on immunostaining are difficult to make.

Together these data underline the complexities of developmental regulation of a single metabotropic glutamate receptor. The other metabotropic receptors may show similar complex profiles in their regulation in different regions of the brain. Given the temporal and spatial complexities of receptor expression and the interactions with other glutamate receptors, understanding the role of mGluR 1 in early neuronal development will require a great deal of further examination.

\section{References}

Abe T, Sugihara H, Nawa H, Shigemoto R, Mizuno N, Nakanishi S (1992) Molecular characterization of a novel metabotropic glutamate receptor mGluR 5 coupled to inositol phosphate/ $\mathrm{Ca}^{2+}$ signal transduction. J Biol Chem 267:13361-13368.

Aramori I, Nakanishi S (1992) Signal transduction and pharmacological characteristics of a metabotropic glutamate receptor, mGluR1, in transfected CHO cells. Neuron 8:757-765.

Armstrong WE, Warach S, Hatton GI, McNeill TH (1980) Subnuclei in the rat paraventricular nucleus: a cytoarchitectural, HRP, and immunocytochemical analysis. Neuroscience 206:317-345.

Arnauld E, Cirino M, Layton BS, Renaud LP (1983) Contrasting actions of amino acids, acetylcholine, noradrenalinc, and lcucine cnkephalin on the excitability of supraoptic vasopressin-secreting neurons. Neuroendocrinology 36:187-196. 
Balduini W, Candura SM, Costa LG (1991) Regional development of carbachol-, glutamate-, norepinephrine-, and serotonin-stimulated phosphoinositide metabolism in rat brain. Dev Brain Res 62:115120.

Bessho Y, Nawa H, Nakanishi S (1993) Glutamate and quisqualate regulate expression of metabotropic glutamate receptor mRNA in cultured cerebellar granule cells. J Neurochem 60:253-259.

Bina K, Cornell-Bell AH, van den Pol AN (1993) Metabotropic glutamate receptors regulate calcium in cultured neurons and glia from the suprachiasmatic nucleus. Soc Neurosci Abstr 19:1815.

Blackstone CD, Levey AI, Martin LJ, Price DL, Huganir RL (1992a) Immunological detection of glutamate receptor subtypes in human central nervous system. Ann Neurol 31:680-683.

Blackstone CD, Moss SJ, Martin LJ, Levey AI, Price DL, Huganir RL (1992b) Biochemical characterization and localization of a non- $N$ methyl-D-aspartate glutamate receptor in rat brain. J Neurochem 58: $1118-1126$.

Boss V, Desai MA, Smith TS, Conn PJ (1992) Trans-ACPD-induced phosphoinositide hydrolysis and modulation of hippocampal pyramidal cell excitability do not undergo parallel developmental regulation. Brain Res 594:181-188.

Brann DW, Mahesh VB (1992) Excitatory amino acid neurotransmission. Evidence for a role in neuroendocrine regulation. Trends Endocrinol Metab 3:122-126.

Cahill GM, Menaker M (1989) Effects of excitatory amino acid receptor antagonists and agonists on suprachiasmatic nucleus responses to retinohypothalamic tract volleys. Brain Res 479:76-82.

Castel M, Belenky M, Cohen S, Ottersen OP, Storm-Mathisen J (1993) Glutamate-like immunoreactivity in retinal terminals of the mouse suprachiasmatic nucleus. Eur J Neurosci 5:368-381.

Cline HT, Constantine-Paton M (1990) NMDA receptor agonist and antagonists alter RGC terminal morphology in the frog retinotectal projection. J Neurosci 10:1 197-1216.

Constantine-Paton M, Cline HT, Debski E (1990) Patterned activity, synaptic convergence, and the NMDA receptor in the developing visual pathways. Annu Rev Neurosci 13:129-154.

Cornell-Bell AH, Finkbeiner SM, Cooper MS, Smith SJ (1990) Glutamate induces calcium waves in cultured astrocytes: long-range glial signaling. Science 247:470-473.

Dudek SM, Bear MF (1989) A biochemical correlate of the critical period for synaptic modification in the visual cortex. Science 246: 673-675.

Dudek SM, Bowen WD, Bear MГ (1989) Postnatal changes in glutamate stimulated phosphoinositide turnover in rat neocortical synaptoneurosomes. Dev Brain Res 47:123-128.

Feinberg AP, Vogelstein B (1983) A technique for radiolabelling DNA restriction endonuclease fragment to high specific activity. Anal Biochem 132:6-11.

Finkbeiner SM (1991) Calcium-mediated glutamate responses in cultured hippocampus, pp 1-353. PhD thesis, Yale University.

Finkbeiner S (1992) Calcium waves in astrocytes - filling in the gaps. Neuron 8:1101-1108

Forscher P, Kaczmarek LK, Buchanan JA, Smith SJ (1987) Cyclic AMP induces changes in distribution and transport of organelles within growth cones of Aplysia bag cell neurons. J Neurosci 7:3600-3611.

Fotuhi M, Sharp AH, Glatt CE, Hwang PM, von Krosigk M, Snyder SH, Dawson TM (1993) Differential localization of phosphoinositide-linked metabotropic glutamate receptor (mGluR 1) and the inositol 1,4,5-triphosphate receptor in rat brain. J Neurosci 13:20012012.

Furuya S, Ohmori H, Shigemoto T, Sugiyama H (1989) Intracellular calcium mobilization triggered by a glutamate receptor in rat cultured hippocampal cells. J Physiol (Lond) 414:539-548.

Gasic GP, Hollmann M (1992) Molecular neurobiology of glutamate receptors. Annu Rev Physiol 54:507-536.

Glaum SR, Miller RJ (1993) Activation of metabotropic glutamate receptors produces reciprocal regulation of ionotropic glutamate and $\mathrm{GABA}$ responses in the nucleus of the tractus solitarius of the rat. $\mathbf{J}$ Neurosci 13:1636-1641.

Gribkoff VK (1991) Electrophysiological evidence for $N$-methyl-Daspartate excitatory amino acid receptors in the rat supraoptic nucleus in vitro. Neurosci Lett 131:260-262.

Gribkoff V, Dudek FE (1990) The effects of excitatory amino acid antagonists on synaptic responses of supraoptic neurons in slices of rat hypothalamus. J Neurophysiol 63:60-71.

Guiramand J, Sassetti I, Recasens M (1989) Developmental changes in the chemosensitivity of rat brain synaptoncurosomes to excitatory amino acids, estimated by inositol phosphate formation. Int $\mathrm{J}$ Dev Neurosci 7:257-266.

Heacock AM, Fisher SK, Agranoff BW (1987) Enhanced coupling of neonatal muscarinic receptors in rat brain to phosphoinositide turnover. J Neurochem 48:1904-1911.

Hollmann M, O'Shea-Greenfield A, Roger S, Heinemann S (1989) Cloning by functional expression of a member of the glutamate receptor family. Nature 342:643-648.

Hollmann M, Hartley M, Heinemann S (1991) Calcium permeability of KA-AMPA-gated glutamate receptor channels depends on subunit composition. Science 252:851-853.

Houamed KM, Kuijper JL, Gilbert TL, Haldeman BA, O'Hara PJ, Mulvihill ER, Almers W, Hagen FS (1991) Cloning, expression, and gene structure of a $G$ protcin-coupled glutamate receptor from a rat brain. Science 252:1318-1321.

Hu B, Bourque CW (1992) NMDA receptor-mediated rhythmic bursting activity in rat supraoptic nucleus neurones in vitro. $\mathrm{J}$ Physiol (Lond) 458:667-687.

Hume RI, Dingledine R, Heinemann SF (1991) Identification of a site in glutamate receptor subunits that controls calcium permeability. Science 253:1028-1030.

Kim YI, Dudek FE (1991) Intracellular electrophysiological study of suprachiasmatic nucleus neurones in rodents: excitatory synaptic mechanisms. J Physiol (Lond) 444:269-287.

Liou SY, Shibata S, Iwasaki K, Ueki S (1986) Optic nerve stimulationinduced increase of release of ${ }^{3} \mathrm{H}$-glutamate and $3 \mathrm{H}$-aspartate but not ${ }^{3} \mathrm{H}-\mathrm{GABA}$ from the suprachiasmatic nucleus in slices of rat hypothalamus. Brain Res Bull 16:527-531.

LoTurco JJ, Krigstein AR (1991) Clusters of coupled neuroblasts in embryonic neocortex. Science 252:563-566.

Martin LJ, Blackstone CD, Huganir RL, Price DL (1992) Cellular localization of a metabotropic glutamate receptor in rat brain. Neuron $9: 259-270$

Masu M, Tanabe Y, Tsuchida K, Shigemoto R, Nakanishi S (1991) Sequence and expression of a metabotropic glutamate receptor. Nature 349:760-765.

Mattson MP, Ping D, Kater SB (1988) Outgrowth-regulating actions of glutamate in isolated hippocampal pyramidal neurons. J Neurosci 8:2087-2100.

Mayer ML, Miller RJ (1990) Excitatory amino acid receptors, second messengers and regulation of intracellular $\mathrm{Ca}^{2+}$ in mammalian neurons. Trends Pharmacol Sci 11:254-260.

McDonald JW, Schoepp DD (1992) The metabotropic excitatory amino acid receptor agonist $1 S, 3 R$-ACPD selectively potentiates $N$-methyl-D-aspartate-induced brain injury. Eur J Pharmacol 21 5:353-354.

Meeker RB, Swanson DJ, Hayward JN (1989) Light and electron microscopic localization of glutamate immunoreactivity in the supraoptic nucleus of the rat hypothalamus. Neuroscience 33:157-167.

Moriyoshi K, Masu M, Ishii T, Shigemoto R, Mizuno N, Nakanishi S (1991) Molecular cloning and characterization of the rat NMDA receptor. Nature 354:31-37.

Nakanishi S (1992) Molecular diversity of glutamate receptors and implications for brain function. Science 258:597-603.

Nicoletti F, Iadarola MJ, Wroblewski JT, Costa E (1986) Excitatory amino acid recognition sites coupled with inositol phospholipid metabolism: developmental changes and interaction with $\alpha 1$-adrenoceptors. Proc Natl Acad Sci USA 83:1931-1935.

Palmer E, Nangel-Taylor K, Krause JD, Roxas A, Cotman CW (1990) Changes in excitatory amino acid modulation of phosphoinositide metabolism during development. Dev Brain Res 51:132-134.

Pin JP, Waeber C, Prezeau L, Bockaert J, Heinemann SF (1992) Alternative splicing generates metabotropic glutamate receptors inducing different patterns of calcium release in Xenopus oocytes. Proc Natl Acad Sci USA 89:10331-10335.

Schoepp D, Bockaert J, Sladeczek F (1990) Pharmacological and functional characteristics of metabotropic excitatory amino acid receptors. Trends Pharmacol Sci 11:508-515.

Shigemoto R, Nakanishi S, Mizuno N (1992) Distribution of the mRNA for a metabotropic glutamate receptor (mGluR1) in the central nervous system: an in situ hybridization study in adult and developing rat. J Comp Neurol 322:121-135.

Siliprandi R, Lipartiti M, Fadda E, Sautter J, Manev H (1992) Activation of the glutamate metabotropic receptor protects retina against $N$-methyl-D-aspartate toxicity. Eur J Pharmacol 219:173-174.

Sortino MA, Nicoletti F, Canonico PL (1991) Metabotropic glutamate 
receptors in the hypothalamus: characterization and developmental profile. Dev Brain Res 61:169-172.

Sugiyama H, Ito I, Hirono C (1987) A new type of glutamate receptor linked to inositol phospholipid metabolism. Nature 325:531-533.

Swandulla D, Misgeld U (1990) Development and properties of synaptic mechanisms in a network of rat hypothalamic neurons grown in culture. J Neurophysiol 64:715-726.

Swanson LW, Kuypers HGJM (1980) The paraventricular nucleus of the hypothalamus: cytoarchitectonic subdivisions and the organization of projections to the pituitary, dorsal vagal complex and spinal cord as demonstrated by the retrograde fluorescence double labeling methods. J Comp Neurol 194:555-570.

Tanabe Y, Masu M, Ishii T, Shigemoto R, Nakanishi S (1992) A family of metabotropic glutamate receptors. Neuron 8:169-179.

van den Pol AN (1982) The magnocellular and parvocellular paraventricular nucleus of rat: intrinsic organization. J Comp Neurol 206 : 317-345.

van den Pol AN (1991) Glutamate and aspartate immunoreactivity in hypothalamic presynaptic axons. J Neurosci 11:2087-2101.

van den Pol AN, Dudek FE (1993) Cellular communication in the circadian clock, the suprachiasmatic nucleus. Neuroscience 56:793811.

van den Pol AN, Trombley PQ (1993) Glutamate neurons in hypothalamus regulate excitatory transmission. J Neurosci 13:2829-2836. van den Pol AN, Wuarin JP, Dudek FF. (1990) Glutamate, the dominant excitatory transmitter in neuroendocrine regulation. Science 250:1276-1278

van den Pol AN, Finkbeiner SM, Cornell-Bell $\Lambda H$ (1992) Calcium excitability and oscillations in suprachiasmatic nucleus neurons and glia in vitro. J Neurosci 12:2648-2664.

van den Pol AN, Kogelman L, Ghush P, Blackstone C (1993) Metabotropic glutamate receptor gene expression in the developing hypothalamus. Soc Neurosci Abstr 19:474.

van den Pol AN, Hermans-Borgmeyer I, Hofer M, Ghosh P, Heinemann $\mathrm{S}$ (1994) Ionotropic glutamate-receptor gene expression in hypothalamus: localization of AMPA, kainate, and NMDA receptor RNA with in situ hybridization. J Comp Neurol, in press.

Verdoorn TA, Burnashev N, Monyer H, Seeburg PH, Sakmann B (1991) Structural determinants of ion flow through recombinant glutamate receptor channels. Science 252:1715-1718.

Wuarin JP, Dudek FE (1991) Excitatory amino acid antagonists inhibit synaptic responses in the guinea pig hypothalamic paraventricular nucleus. J Neurophysiol 65:946-951.

Yuzaki M, Mikoshiba K (1992) Pharmacological and immunocytochemical characterization of metabotropic glutamate receptors in cultured purkinje cells. J Neurosci 12:4253-4263. 